Review

\title{
Advances in Endoscopic Photoacoustic Imaging
}

\author{
Yan Li ${ }^{1}(\mathbb{D})$ Gengxi Lu ${ }^{2}\left(\mathbb{D}\right.$, Qifa Zhou $^{2}$ and Zhongping Chen ${ }^{1,3,4, *(\mathbb{D})}$ \\ 1 Beckman Laser Institute, University of California Irvine, Irvine, CA 92617, USA; yanl30@uci.edu \\ 2 Roski Eye Institute, Keck School of Medicine, University of Southern California, \\ Los Angeles, CA 90033, USA; gengxilu@usc.edu (G.L.); qifazhou@usc.edu (Q.Z.) \\ 3 The Edwards Lifesciences Center for Cardiovascular Technology, University of California Irvine, \\ Irvine, CA 92617, USA \\ 4 Department of Biomedical Engineering, University of California Irvine, Irvine, CA 92697, USA \\ * Correspondence: z2chen@uci.edu
}

check for

updates

Citation: Li, Y.; Lu, G.; Zhou, Q.; Chen, Z. Advances in Endoscopic Photoacoustic Imaging. Photonics 2021, 8, 281. https://doi.org/ $10.3390 /$ photonics 8070281

Received: 3 June 2021

Accepted: 13 July 2021

Published: 16 July 2021

Publisher's Note: MDPI stays neutral with regard to jurisdictional claims in published maps and institutional affiliations.

\section{Copyright: (c) 2021 by the authors.} Licensee MDPI, Basel, Switzerland. This article is an open access article distributed under the terms and conditions of the Creative Commons Attribution (CC BY) license (https:/ / creativecommons.org/licenses/by/ $4.0 /)$.

\begin{abstract}
Photoacoustic (PA) imaging is able to provide extremely high molecular contrast while maintaining the superior imaging depth of ultrasound (US) imaging. Conventional microscopic PA imaging has limited access to deeper tissue due to strong light scattering and attenuation. Endoscopic PA technology enables direct delivery of excitation light into the interior of a hollow organ or cavity of the body for functional and molecular PA imaging of target tissue. Various endoscopic PA probes have been developed for different applications, including the intravascular imaging of lipids in atherosclerotic plaque and endoscopic imaging of colon cancer. In this paper, the authors review representative probe configurations and corresponding preclinical applications. In addition, the potential challenges and future directions of endoscopic PA imaging are discussed.
\end{abstract}

Keywords: endoscopic photoacoustic image; ultrasound image

\section{Introduction}

To access comprehensive structural and functional information of internal organs, various imaging technologies, such as optical coherence tomography (OCT), ultrasound (US), and near infrared fluorescence (NIRF) imaging have been developed for endoscopic imaging and used in clinical applications. The main advantage of US and OCT lies in their capability of providing cross-sectional structural information, revealing the underlying layered structure of the biological tissue. US has a large penetration depth and can reveal information that lies in the deeper layers of the tissue. Benefiting from its micron-scale resolution, OCT has the capability to visualize tissue with more details. Near infrared fluorescence and spectroscopy (NIRF and NIRS) are capable of providing molecular contrast with high sensitivity and resolution, but it lacks depth information. Multiphoton can provide high resolution optical sectioning with an imaging depth of several hundreds of micrometers, but it has a limited field of view. Table 1 summarizes the strengths and limitations of these imaging techniques. As shown, no single technique can provide depth resolved structural and functional information simultaneously.

Table 1. Performance comparison of endoscopic imaging modalities.

\begin{tabular}{ccccc}
\hline & Resolutuon & Molecular Contrast & Imaging Depth & Main Limitation \\
\hline OCT [1] & $\begin{array}{c}\text { Axial: } \sim 10 \mu \mathrm{m} \\
\text { Lateral: } \sim 30 \mu \mathrm{m}\end{array}$ & $\mathrm{N}$ & $1-2 \mathrm{~mm}$ & $\begin{array}{c}\text { Shallow penetration } \\
\text { No molecular contrast }\end{array}$ \\
\hline US [2] & $\begin{array}{c}\text { Axial: } \sim 100 \mu \mathrm{m} \\
\text { Lateral: } \sim 300 \mu \mathrm{m}\end{array}$ & $\mathrm{N}$ & $<6 \mathrm{~cm}$ & $\begin{array}{c}\text { Low resolution } \\
\text { No molecular contrast }\end{array}$ \\
\hline NIRF/NIRS & Lateral: $\sim 10 \mu \mathrm{m}$ & $\mathrm{Y}$ & Surface & No depth information \\
\hline Multiphoton [3] & $\begin{array}{c}\text { Axial: } 12 \mu \mathrm{m} \\
\text { Lateral: } 0.8 \mu \mathrm{m}\end{array}$ & $\mathrm{Y}$ & $\sim 300 \mu \mathrm{m}$ & $\begin{array}{c}\text { Limited field of view } \\
\text { Slow imaging speed }\end{array}$ \\
\hline PA & $\begin{array}{c}\text { Axial: } \sim 100 \mu \mathrm{m} \\
\text { Lateral: } \sim 20-300 \mu \mathrm{m}\end{array}$ & $\mathrm{Y}$ & $<6 \mathrm{~cm}$ & - \\
\hline
\end{tabular}


Photoacoustic (PA) imaging, an emerging biomedical imaging modality, has the advantage of providing optical absorption contrast with a greater penetration depth compared with conventional optical imaging modalities [4-12]. In PA imaging, the biological tissue is irradiated by a pulsed light. A portion of the optical energy is absorbed by tissue and converted into heat, resulting in a transient pressure rise. This initial pressure acts as an acoustic source that generates an acoustic wave propagating through the tissue. An ultrasonic transducer is often used for detecting the acoustic wave to form PA images. Due to the introduction of a US transducer, US imaging can be incorporated seamlessly. Alternatively, an all optical US sensor, such as a Fabry-Pérot interferometer and microresonator, can be also applied to detect a generated PA signal [13-20]. The intensity of the generated PA signal is proportional to the local absorption coefficient of the tissue, the light intensity, and the Grüneisen parameter, which represents thermoacoustic conversion efficiency. Different biological tissues exhibit different absorption spectra, as shown in Figure 1. Absorption spectra can be used to image and identify a specific tissue chromophore when excited at specific wavelengths that are coincident with the corresponding absorption peaks. For example, $1210 \mathrm{~nm}$ and $1720 \mathrm{~nm}$ are often used to map lipids in an atherosclerotic lesion [21-26], and $532 \mathrm{~nm}$ are often chosen to image vasculature [27-29]. The depth information can be reconstructed by measuring the time of arrival of generated acoustic waves. For endoscopic PA imaging, a miniatured imaging probe is involved, which usually consists of an optical fiber for light delivery and a US sensor for PA signal detection.

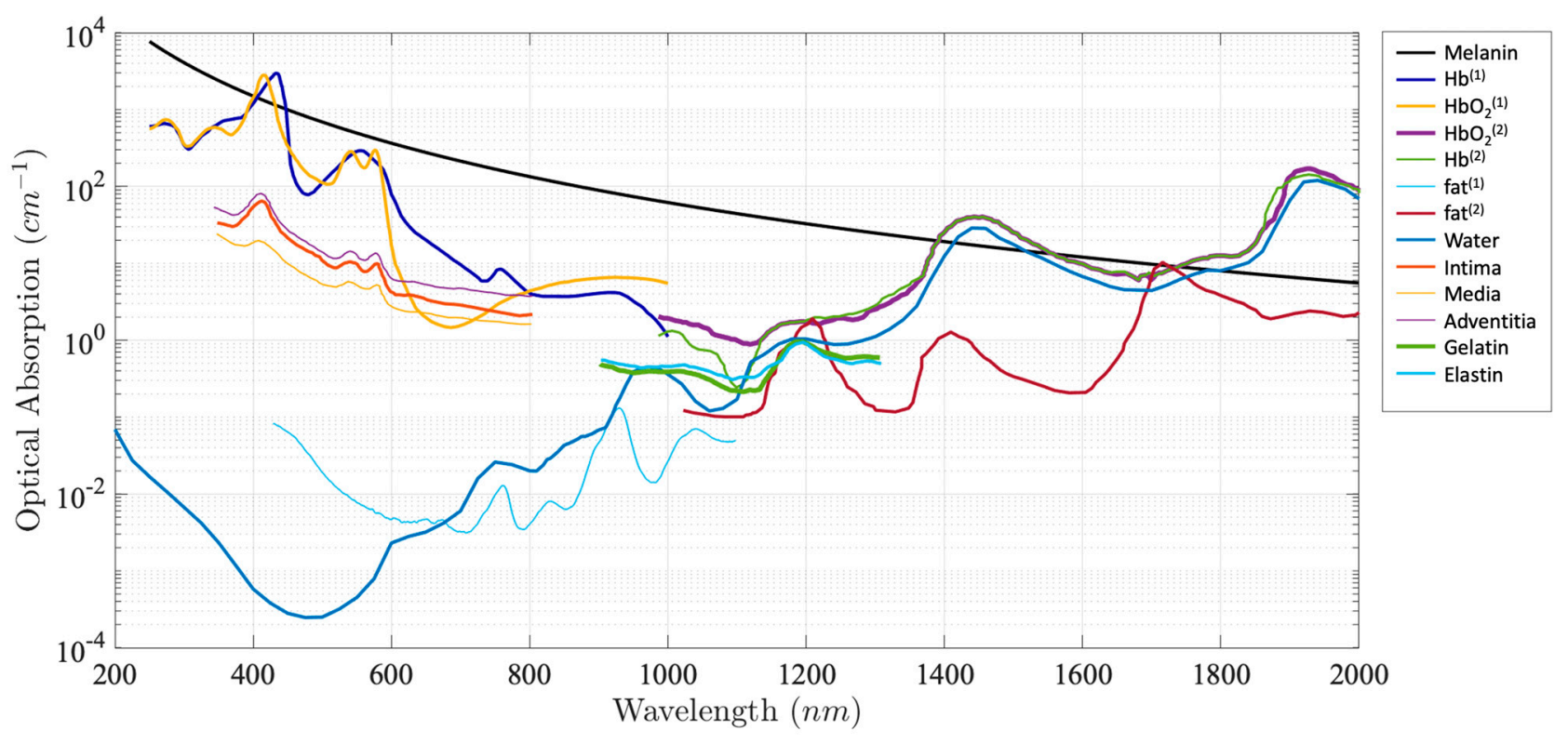

Figure 1. Absorption coefficient spectra of endogenous tissue chromophores [30-33].

As an extension of PA imaging, spectroscopic PA imaging can be performed by applying multiwavelength laser excitation and a spectroscopic analysis for tissue characterization and quantification due to tissue unique spectral signatures. Spectroscopic PA imaging has been investigated in a wide variety of applications. For example, spectroscopic PA has been applied in intravascular imaging to detect and distinguish peri-adventitial and atherosclerotic lipids, one of the main characteristics of vulnerable plaque [7,34,35]. Another important application is to measure blood oxygen saturation $\left(\mathrm{SO}_{2}\right)$, which is a key factor for cancer detection and staging, using the differences in oxyhemoglobin $\left(\mathrm{HbO}_{2}\right)$ and deoxyhemoglobin $(\mathrm{HHb})[36,37]$.

In addition to intrinsic contrast, exogenous optical contrast agents such as gold nanoparticles and indocyanine green (ICG) have been investigated for PA imaging to further enhance the PA signal or provide additional optical contrast. For example, several studies have reported that ICG is able to target lipid loaded macrophages, which can be 
used in intravascular imaging for vulnerable plaque characterization [38,39]. However, safety will be a main concern if exogenous contrast agents are introduced.

Representative endoscopic PA imaging system and probe design have been reported in recent review articles [40,41]. In this review paper, we will focus on the comparison of different probe designs and further summarize a representative PA imaging system with key parameters of performance.

\section{Endoscopic Photoacoustic Imaging System}

Figure 2 depicts the schematic of a representative endoscopic PA imaging system setup [29]. A nanosecond pulsed laser is used for PA signal excitation. The output laser beam is focused by a condenser lens into the imaging probe to excite the target tissue. A US transducer is used to detect the generated PA signal. Due to the introduction of a US transducer, US imaging can be performed simultaneously. To separate PA and US signals, a delay unit is often applied to delay US pulse emission by a few nanoseconds. For radial scanning, a scanner consisting of an optical rotary joint and slip ring can be utilized to pass optical and electrical signals across rotating interfaces. With this scanning mechanism, the imaging probe can be miniaturized in terms of outer diameter and rigid length. However, nonuniform rotation distortion (NURD) will be a main concern, especially for intravascular imaging. Alternatively, a micromotor can be incorporated into the imaging probe tip to rotate the mirror only, instead of the entire imaging probe. This scanning mechanism will enable uniform rotation at the cost of increased rigid length. Tables 2 and 3 show representative endoscopic PA imaging systems and corresponding key parameters.

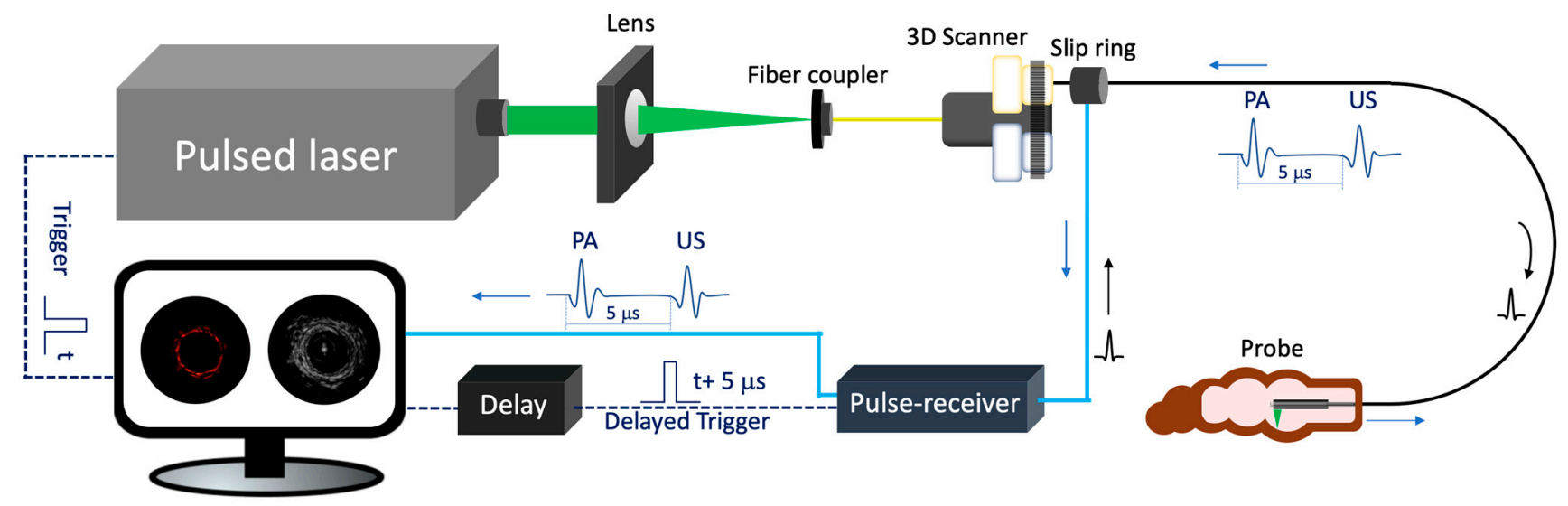

Figure 2. Endoscopic photoacoustic and ultrasound imaging system. PA: photoacoustic. US: ultrasound. 
Table 2. Representative endoscopic photoacoustic imaging systems for GI tract.

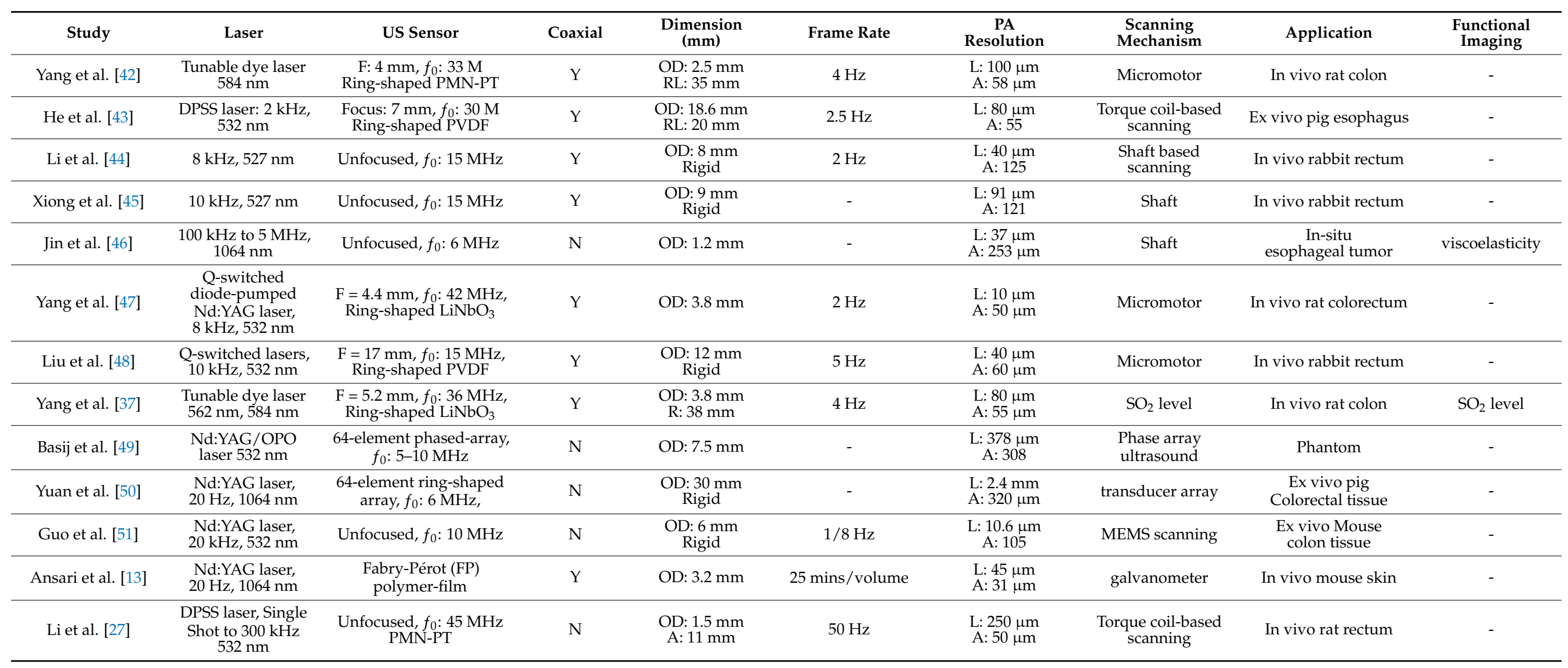


Table 3. Representative intravascular photoacoustic imaging systems.

\begin{tabular}{|c|c|c|c|c|c|c|c|c|c|}
\hline Study & Laser & US Sensor & Coaxial & $\begin{array}{c}\text { Dimension } \\
(\mathrm{mm})\end{array}$ & Frame Rate & $\begin{array}{c}\text { PA } \\
\text { Resolution }\end{array}$ & $\begin{array}{l}\text { Scanning } \\
\text { Mechanism }\end{array}$ & Application & $\begin{array}{l}\text { Functional } \\
\text { Imaging }\end{array}$ \\
\hline Ji et al. [52] & $\begin{array}{l}\text { OPO laser, } 10 \mathrm{~Hz}, \\
750 \mathrm{~nm}\end{array}$ & $\begin{array}{c}\text { dual element unfocused } \\
\text { transducer } \\
f_{0}: 19 \mathrm{MHz}\end{array}$ & $\mathrm{N}$ & $\begin{array}{l}\text { OD: } 1.2 \mathrm{~mm} \\
\text { R: } 20 \mathrm{~mm}\end{array}$ & - & $\begin{array}{l}\mathrm{L}: 13 \mu \mathrm{m} \\
\mathrm{A}: 127 \mu \mathrm{m}\end{array}$ & $\begin{array}{c}\text { Torque, coil } \\
\text { based scanning }\end{array}$ & Ex vivo rabbit aorta & - \\
\hline Piao et al. [24] & $\begin{array}{c}\text { OPO laser, } 500 \mathrm{~Hz}, \\
1725 \mathrm{~nm}\end{array}$ & Unfocused, $f_{0}: 45 \mathrm{MHz}$ & $\mathrm{N}$ & $\begin{array}{l}\text { OD: } 1 \mathrm{~mm} \\
\text { R: } 6 \mathrm{~mm}\end{array}$ & $1 \mathrm{~Hz}$ & $\begin{array}{l}\mathrm{L}: 350 \mu \mathrm{m} \\
\mathrm{A}: 60 \mu \mathrm{m}\end{array}$ & $\begin{array}{c}\text { Torque, coil } \\
\text { based scanning }\end{array}$ & Ex vivo rabbit aorta & \\
\hline Wang et al. [54] & $\begin{array}{l}\text { OPO laser, } 10 \mathrm{~Hz}, \\
1720 \mathrm{~nm}\end{array}$ & $\begin{array}{l}\text { Unfocused, } \\
f_{0}: 40 \mathrm{MHz}\end{array}$ & $\mathrm{N}$ & OD: $2.2 \mathrm{~mm}$ & - & - & $\begin{array}{c}\text { Torque, coil } \\
\text { based scanning }\end{array}$ & $\begin{array}{l}\text { In vivo } \\
\text { rabbit aorta with blood }\end{array}$ & - \\
\hline Mathews et al. [14] & $\begin{array}{l}\text { Tunable dye laser, } \\
565 \text { to } 605 \mathrm{~nm}\end{array}$ & $\begin{array}{l}\text { Fabry-Pérot (FP) } \\
\text { polymer film }\end{array}$ & $\mathrm{N}$ & OD: $1.25 \mathrm{~mm}$ & $1 / 15 \mathrm{~Hz}$ & $\begin{array}{l}\mathrm{L}: 18 \mu \mathrm{m} \\
\mathrm{A}: 45 \mu \mathrm{m}\end{array}$ & $\begin{array}{c}\text { Torque, coil } \\
\text { based scanning }\end{array}$ & Phantom & - \\
\hline Zhang et al. [55] & $\begin{array}{l}\text { OPO laser, } 10 \mathrm{~Hz}, \\
720,760 \mathrm{~nm}\end{array}$ & $\begin{array}{l}\text { Unfocused, } \\
f_{0}: 20 \mathrm{MHz}\end{array}$ & $\mathrm{N}$ & OD: $1.8 \mathrm{~mm}$ & - & $\begin{array}{l}\mathrm{L}: 380 \mu \mathrm{m} \\
\quad \mathrm{A}: 100\end{array}$ & $\begin{array}{c}\text { Torque, coil } \\
\text { based scanning }\end{array}$ & $\begin{array}{c}\text { In vivo } \\
\text { rabbit aorta with blood }\end{array}$ & $\begin{array}{l}\text { Spectroscopic } \\
\text { imaging }\end{array}$ \\
\hline Wang et al. [56] & $\begin{array}{l}\text { OPO laser, } 10 \mathrm{~Hz}, \\
1700 \mathrm{~nm}\end{array}$ & $\begin{array}{l}\text { Unfocused, } \\
f_{0}: 15 \mathrm{MHz}\end{array}$ & $\mathrm{N}$ & OD: $1.1 \mathrm{~mm}$ & - & $\begin{array}{l}\text { L: } 94 \mu \mathrm{m} \\
\text { A: } 122 \mu \mathrm{m}\end{array}$ & $\begin{array}{c}\text { Torque, coil } \\
\text { based scanning }\end{array}$ & Ex vivo rabbit aorta & $\begin{array}{l}\text { Elasticity } \\
\text { imaging }\end{array}$ \\
\hline Xie et al. [57] & $\begin{array}{c}8 \mathrm{kHz} \text { to } 100 \mathrm{kHz} \\
1064 \mathrm{~nm}\end{array}$ & $\begin{array}{c}\text { Unfocused, } f_{0}: 40 \mathrm{MHz} \\
\text { PZT }\end{array}$ & $\mathrm{N}$ & OD: $0.9 \mathrm{~mm}$ & $100 \mathrm{~Hz}$ & - & $\begin{array}{c}\text { Torque, coil } \\
\text { based scanning }\end{array}$ & $\begin{array}{l}\text { In vivo rabbit aorta with } \\
\text { nanoparticles }\end{array}$ & - \\
\hline Hui et al. [21] & $\begin{array}{l}\text { KTP-based OPO, } \\
500 \mathrm{~Hz}, 1724 \mathrm{~nm}\end{array}$ & $\begin{array}{c}\mathrm{F}: 3 \mathrm{~mm}, f_{0}: 35 \mathrm{MHz} \\
\text { Ring-shaped }\end{array}$ & $\mathrm{Y}$ & OD: $>2.5 \mathrm{~mm}$ & $1 \mathrm{~Hz}$ & $\begin{array}{l}\mathrm{L}: 260 \mu \mathrm{m} \\
\mathrm{A}: 102 \mu \mathrm{m}\end{array}$ & $\begin{array}{c}\text { Torque, coil } \\
\text { based scanning }\end{array}$ & $\begin{array}{c}\text { Ex vivo human femoral } \\
\text { artery }\end{array}$ & - \\
\hline Wu et al. [25] & $\begin{array}{c}\text { Periodically-poled } \\
\mathrm{LiNbO}_{3} \mathrm{OPO}, 5 \mathrm{kHz} \\
1720 \mathrm{~nm}\end{array}$ & Unfocused, $f_{0}: 40 \mathrm{MHz}$ & $\mathrm{N}$ & $\begin{array}{l}\text { OD: } 1.3 \mathrm{~mm} \\
\text { with sheath }\end{array}$ & $20 \mathrm{~Hz}$ & - & $\begin{array}{c}\text { Torque, coil } \\
\text { based scanning }\end{array}$ & $\begin{array}{l}\text { In vivo swine coronary } \\
\text { lipid model }\end{array}$ & - \\
\hline Lei et al. [58] & $\begin{array}{c}\text { OPO laser, } 2.5 \mathrm{kHz}, \\
1720 \mathrm{~nm}\end{array}$ & Unfocused, $f_{0}: 50 \mathrm{MHz}$ & $\mathrm{N}$ & $0.7 \mathrm{~mm}$ & $5 \mathrm{~Hz}$ & $\begin{array}{l}\mathrm{L}: 209 \mu \mathrm{m} \\
\mathrm{A}: 61 \mu \mathrm{m}\end{array}$ & $\begin{array}{c}\text { Torque, coil } \\
\text { based scanning }\end{array}$ & $\begin{array}{c}\text { Ex vivo thoracic aorta } \\
\text { mouse }\end{array}$ & - \\
\hline Bai et al. [59] & $\begin{array}{l}\text { OPO laser, } 10 \mathrm{~Hz}, \\
1210 \mathrm{~nm} \\
\end{array}$ & $\begin{array}{c}\text { Unfocused, } f_{0}: 40 \mathrm{MHz} \\
\text { PZT }\end{array}$ & $\mathrm{N}$ & $1.1 \mathrm{~mm}$ & $1 / 160 \mathrm{~Hz}$ & $\begin{array}{l}\mathrm{L}: 19.6 \mu \mathrm{m} \\
\mathrm{A}: 38.1 \mu \mathrm{m}\end{array}$ & $\begin{array}{c}\text { Torque, coil } \\
\text { based scanning }\end{array}$ & Ex vivo phantom & - \\
\hline Li et al. [22] & $\begin{array}{l}\text { OPO laser, } 1 \mathrm{kHz} \\
1210 \mathrm{~nm}, 1720 \mathrm{~nm}\end{array}$ & $\begin{array}{c}\text { Unfocused, } f_{0}: 40 \mathrm{MHz} \\
\text { PZT }\end{array}$ & $\mathrm{N}$ & $0.9 \mathrm{~mm}$ & $5 \mathrm{~Hz}$ & $\begin{array}{l}\text { L: } 200 \mu \mathrm{m} \\
\text { A: } 100 \mu \mathrm{m}\end{array}$ & $\begin{array}{c}\text { Torque, coil } \\
\text { based scanning }\end{array}$ & Ex vivo phantom & $\begin{array}{l}\text { Spectroscopic } \\
\text { imaging }\end{array}$ \\
\hline
\end{tabular}


A nanosecond laser is one of the key components of a PA imaging system as its repetition rate determines the maximum imaging speed and its energy affects the signal to noise ratio of the PA signal. In most reported studies, a Q-switched Nd: YAG pumped optical parametric oscillator (OPO), Ti: sapphire, or dye laser systems are used for PA signal excitation, in which a tunable wavelength enables spectroscopic PA imaging [14,37,42,47,52,55]. This OPO often operates at a slow repetition rate $(\sim 10 \mathrm{~Hz})$ and slow tuning speed. In addition, diode pumped solid state (DPSS) lasers have been introduced into PA imaging due to their high power and repetition rate, so that a high frame rate can be achieved $[27,43]$. However, DPSS laser based PA systems are incapable of performing spectroscopic PA imaging due to their single wavelength operation.

One of main technical barriers hindering the clinical translation of PA is the shortage of appropriate laser sources that can provide sufficient pulse energy as well as repetition rate. Although the reported fastest imaging speed for in vivo intravascular PA (IVPA) imaging is 25 frames per second, heavy water was applied to enhance the SNR [60]. In addition, Yang et al. adopted two pulsed lasers (operating at wavelengths of $562 \mathrm{~nm}$ and $584 \mathrm{~nm}$ ), instead of an OPO laser, to perform PA imaging of blood vessels for calculating $\mathrm{SO}_{2}$ saturation to overcome the slow wavelength sweep speed of the OPO laser. The desired laser should have the following features. (1) High repetition rate while maintaining high pulse energy. (2) High wavelength sweep rate and large sweep range. (3) Compact size for practical use.

\section{Endoscopic Photoacoustic Imaging System Probe}

In order to achieve high quality PA images, an optimal imaging probe that includes an optical fiber to deliver excitation light and a US detector for signal detection is essential. Various probes using different types of light delivery, US detection, and scanning mechanisms have been investigated. Each has its own advantages and limitations. Based on clinical applications, these designs can be categorized into two groups: GI tract and intravascular imaging probes.

\subsection{GI Tract Endoscope}

Various GI tract imaging probes have been proposed [6,13,18,27,29,37,42,44,45,47,49-51,61-66], as shown in Figure 3. Yang et al. reported a series of micromotor based endoscopic PA probes $[6,37,42,47,63]$. The probe consists of a ring-shaped US transducer and an optical fiber which is mounted in the central opening of the ultrasonic transducer. A mirror aligned with the fiber tip and US transducer coaxially is driven by a micromotor to reflect both laser and acoustic beams towards the tissue, as shown in Figure 3a. This imaging probe has a limited field of view due to being blocked by the stainless steel wall. In addition, the imaging speed is relatively slow, because the mirror is rotated through a magnetic coupling mechanism in order to isolate the micromotor from water. To address this issue, Xiong et al. [45] and Li et al. [44] reported several similar coaxial PA imaging probes with different scanning mechanisms, in which the entire imaging probe or probe shell was rotated by an external motor at a frequency of $2 \mathrm{~Hz}$. In addition, the ring-shaped US transducer was aligned with the laser beam coaxially and placed near the imaging window, as shown in Figure $3 b$. This configuration will avoid extra US signal attenuation caused by the reflection of the mirror, thereby improving sensitivity. To perform high speed and full field of view imaging, Li et al. [27,29] developed a PA probe with torque coil based scanning, in which optical and acoustic components are arranged in a series. Optical and/or acoustic beams are tilted to achieve an overlap between two beams for effective PA signal detection. The imaging speed is up to $50 \mathrm{~Hz}$. The main limitations include limited imaging range and additional steps for achieving coregistered PA and US images due to longitudinal offset between the two beams. In addition to the radial scanning mechanism, Guo et al. [51] and Qu et al. [64] demonstrated a microelectromechanical systems (MEMS) scanning mirror based imaging probe, as shown in Figure $3 \mathrm{~d}$, which is able to perform fast raster scanning. The maximum scanning frequency of this MEMS mirror is $500 \mathrm{~Hz}$, which can support a $1000 \mathrm{~Hz}$ frame rate with the fast laser. The main limitation is its 
relatively large probe size due to the use of MEMS. To perform cross sectional imaging without scanning, Yuan et al. [50] developed an imaging probe (Figure 3c) based on a ring-shaped array US transducer, in which a transducer and optical fiber were aligned coaxially. A tapered reflector was used to transform the laser beam into a ring- shaped distribution to illuminate the sample and a 64-element ring transducer array connected with the parallel acquisition system was used to detect the generated PA signal, as shown in Figure 3e. Basij et al. [49] present a phased array US transducer based imaging probe, in which six silica core/cladding optical fibers surrounding the US transducer were used to illuminate the sample. In addition to the traditional US transducer, an optical US sensor (such as a micro ring resonator and FP sensors) has been used in endoscopic PA imaging probes $[13,18,65,66]$. Figure $3 f$ shows a representative all optical imaging probe, which consists of a fiber bundle and the Fabry-Pérot (FP) US sensor at the fiber tip [13].
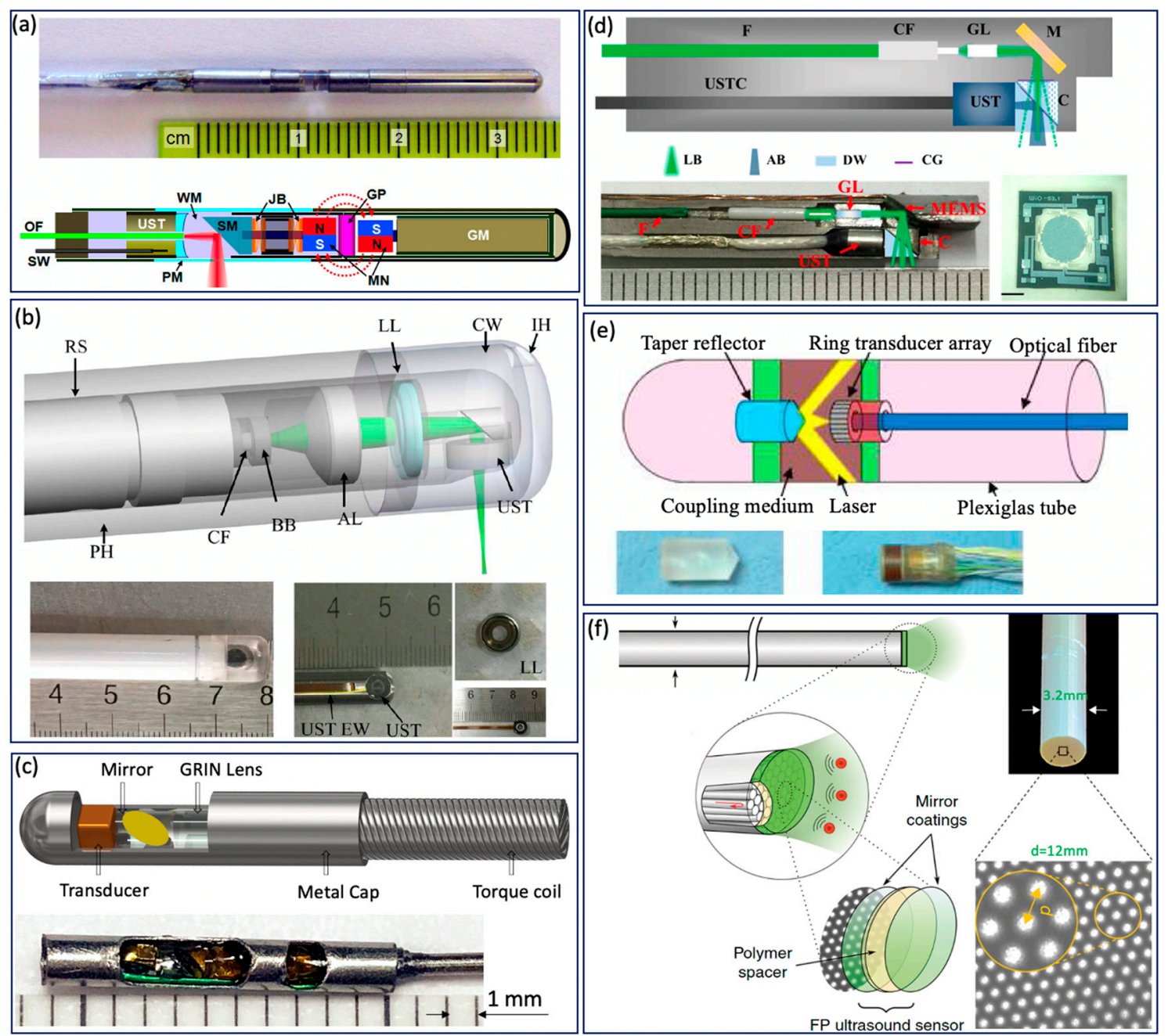

Figure 3. GI Tract PA endoscope. (a) Distal scanning based coaxial imaging probe. GM, geared micromotor; GP, glass partition; JB, jewel bearings; MN, magnets; OF, optical fiber; PM, plastic membrane (imaging window); SM, scanning mirror; SW, signal wire; UST, ultrasonic transducer; WM, water medium. Adapted from [42]. (b) Proximal scanning based coaxial imaging probe. RS, rotating shaft; LL, liquid lens; CW, coupling window; IH, inject hole; $\mathrm{PH}$, plastic housing; $\mathrm{BB}$, ball bearing; CF, ceramic ferrule; AL, aspheric lens; UST, ultrasonic transducer; UST EW, ultrasonic transducer electric wire. Adapted from [45]. (c) Proximal scanning based noncoaxial imaging probe. Adapted from [27]. (d) MEMS based imaging probe. F, fiber; CF, ceramic ferrule; GL, GRIN lens; M, MEMS mirror; UST, ultrasound transducer; USTC, ultra- sound transducer cable; C, cube; LB, light beam; AB, acoustic beam; DW, deionized water; CG, cover glass. Scale bar: $0.5 \mathrm{~mm}$ [51]. (e) Ring-shaped transducer array based imaging probe. Adapted from [50]. (f) All optical PA imaging probe. Adapted from [13]. 


\subsection{Intravascular Imaging Probe}

In contrast to the GI tract imaging probe, an intravascular imaging probe needs to be implemented with a smaller diameter and shorter rigid length in order to realize a smooth advance in the tortuous cardiovascular system. Various probe configurations were reported [11,22-25,67-71], as shown in Figure 4. Wu et al. proposed a $0.8 \mathrm{~mm}$ noncoaxial probe, in which a multimode fiber end was angle polished to enable total reflection for laser delivery and a side-facing US transducer was aligned in a series for PA signal detection. The lateral resolution of this kind of probe is relatively poor due to the broad illumination [25]. With the same alignment, Li et al. [22] introduced a grin lens at the end of the optical fiber to achieve a quasifocusing illumination (Figure $4 \mathrm{~b}$ ). An improved resolution of $\sim 200 \mu \mathrm{m}$ was obtained. To further improve lateral resolution, Zhang et al. applied a graded index multimode fiber to replace a multimode fiber for light propagation, which enables a beam self-cleaning effect and offers a lateral resolution of $30 \mu \mathrm{m}$ [67]. Wang et al. proposed to utilize a tapered fiber (core: from Ø25 to Ø9 $\mu \mathrm{m}$ ) instead of a multimode fiber, which contributes to an optimal lateral resolution of $18 \mu \mathrm{m}$ [68]. However, the above mentioned noncoaxial imaging probes [22,24,25,67-69] have limited imaging range and require additional steps to achieve coregistered PA and US images. To address these issues, Wei et al. [11] and Cao et al. [70] presented coaxial imaging probes, as shown in Figure $4 c, d$, in which optical and acoustic beams share the same optical path. This configuration can be realized by using a ring-shaped US transducer (Figure 4c) or multireflection scheme (Figure $4 \mathrm{~d}$ ), which enables a long imaging range and automatic image coregistration $[11,23,70]$. The limitations of these designs include a relatively large size due to the use of the ring-shaped US transducer and degraded sensitivity caused by multiple reflections of the PA/US signal.
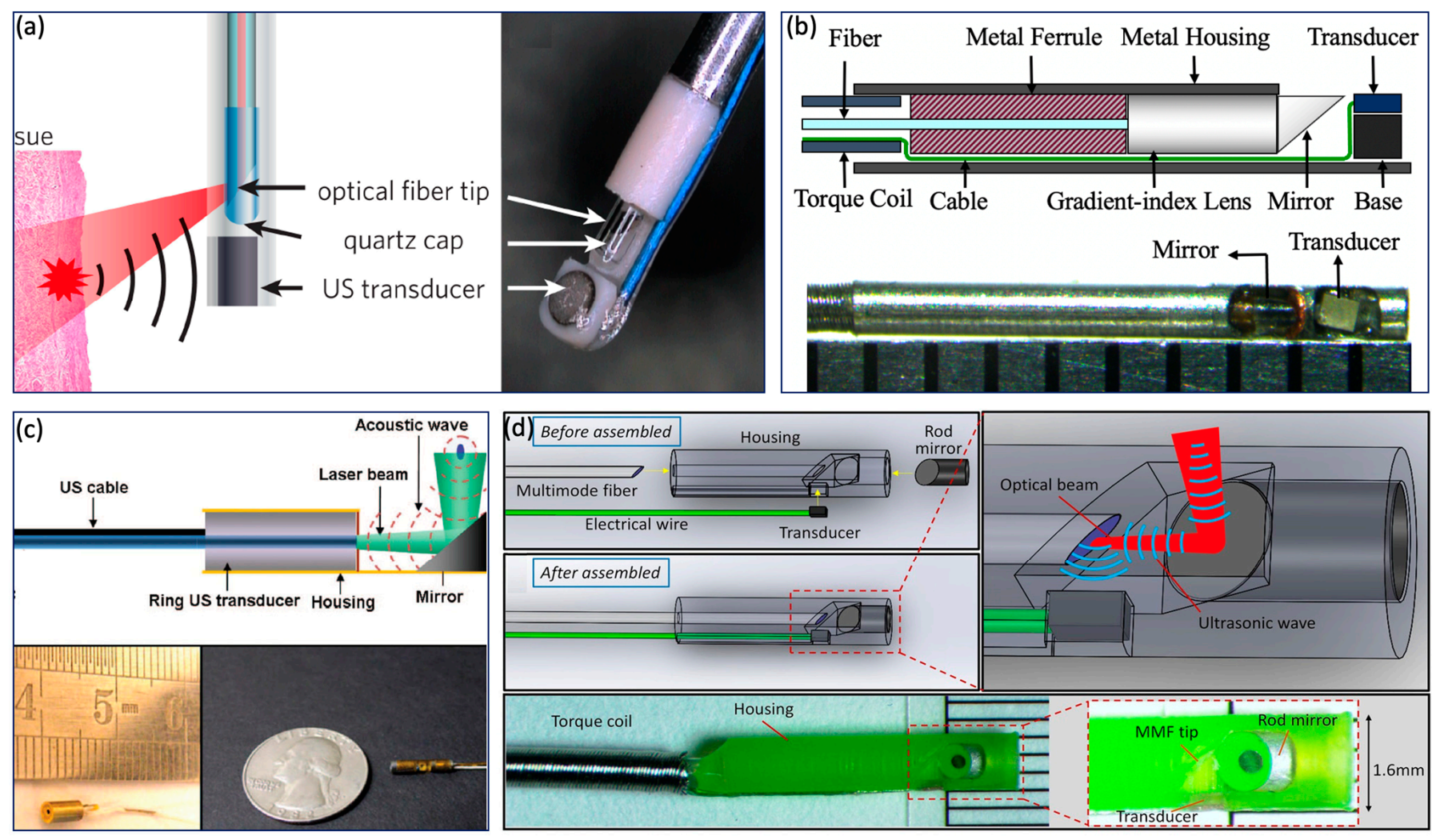

Figure 4. Intravascular imaging probe. (a) Sequential alignment and broad illumination. Adapted from [72]. (b) Sequential alignment and focusing illumination. Adapted from [22]. (c) Coaxial alignment and broad illumination. Adapted from [11]. (d) Coaxial alignment and broad illumination. Adapted from [70]. 


\subsection{Ultrasound Transducer}

In addition to improvement in probe configuration, tremendous efforts have been made to develop a miniature US transducer. The piezoelectric material used in an ultrasonic transducer has a significant influence on the performance of the PA/US imaging system. The widely used piezoelectric materials for endoscopic PA imaging include Polyvinylidene fluoride (PVDF) [73], Lithium niobate ( $\mathrm{LiNbO}_{3}$ or $\mathrm{LNO}$ ) [37,47,63], lead magnesium niobate-lead titanate (PMN-PT) [26,42], and lead zirconate titanate (PZT) [22,28,70]. The typical acoustic and piezoelectric properties are listed in Table 4.

Table 4. The acoustic and piezoelectric properties of common piezoelectric materials. $K_{S}$ : clamped relative dielectric constant. $\mathrm{Z}$ : acoustic impendence. $\mathrm{d}_{33}$ : piezoelectric constant. $\mathrm{K}_{\mathrm{t}}$ : electro-mechanical coupling coefficient. $\mathrm{T}_{\mathrm{C}}$ : Curie temperature.

\begin{tabular}{ccccccc}
\hline Materials & $\mathbf{K}_{\mathbf{x}}$ & $\mathbf{Z}$ (MRayl) & $\mathbf{d}_{\mathbf{3 3}}(\mathbf{p C} / \mathbf{N})$ & $\mathbf{k}_{\mathbf{t}}$ & $\mathbf{T}_{\mathbf{c}}\left({ }^{\circ} \mathbf{C}\right)$ & Bandwidth \\
\hline $\mathrm{LiNbO}_{3}[6,37,47,63,74]$ & 39 & 34.1 & 6.2 & 0.49 & 1210 & $60-70 \%$ \\
\hline PMN-PT $[26,42,75]$ & 797 & 36.9 & $1430-2500$ & $0.58-0.62$ & $130-140$ & $60-80 \%$ \\
\hline PZT $[22,28,70]$ & $850-2500$ & $22-23$ & $500-600$ & $0.51-0.53$ & $150-360$ & $60 \%$ \\
\hline PVDF $[73,76]$ & 6 & $3.9-4.1$ & $20-30$ & $0.15-0.2$ & & $83 \%$ \\
\hline
\end{tabular}

$\mathrm{LiNbO}_{3}$ has the largest Curie temperature $\left(\mathrm{T}_{\mathrm{c}}\right)$ among piezoelectric materials. This provides LNO-based transducers with a stable performance in high pulse repetition frequency (PRF) imaging. In addition, the large $T_{c}$ is especially important for PA/US endoscopy because the high intensity laser used in PA could generate lots of heat in the confined endoscopic probe, which could depolarize the piezoelectric materials.

PZT is one of the most conventional piezoelectric ceramics and has been widely used in various applications. PZT for imaging applications usually has electro-mechanical coupling capabilities $\left(\mathrm{k}_{\mathrm{t}}\right)$ larger than LNO. By modifying the composition of PZT ceramics, piezoelectric properties can be changed within a very wide range. This provides flexibility in transducer design. For example, to match with most control systems and data acquisition systems, a transducer's electrical impedance is usually designed to be $50 \mathrm{Ohms}$. Since PZT's relative clamped dielectric constant ranges from 580 to 2500, a range of the size and center frequencies can be selected.

PMN-PT is a new class of single-crystal piezoelectric materials with improved piezoelectricity. It has the largest piezoelectric strain constant $\left(\mathrm{d}_{33}\right)$ and $\mathrm{k}_{\mathrm{t}}$ (larger than 0.58$)$ compared to other common piezoelectric materials [75,77]. Therefore, a PMN-PT based transducer has better SNR, compared to PZT and 1-3 composite PZT transducers [29,78]. In addition, PMN-PT and certain types of PZT are especially appropriate for minimized intravascular transducers (an aperture size smaller than $0.6 \mathrm{~mm}$ ) due to their high dielectric constant.

PVDF is a soft polymer with unique properties. It has the lowest acoustic impedance compared to other stiff piezoelectric materials. The best acoustic impedance matching to water or biological tissues ( 1.5 MRayls) allows US waves to enter the transducer with the least reflection. This compensates its low $\mathrm{k}_{\mathrm{t}}$ and provides large bandwidth. However, its low dielectric constant highly limits its applications in endoscopy, especially when electrical impedance tuning is unavailable in endoscopic probes.

1-3 composite materials based on bulky piezoelectric materials have been developed for more benefits. Piezoelectric rods in 1-3 composite materials embedded in a low density polymer lower the acoustic impedance and highly enhance the electromechanical coupling coefficient (from 0.58 to 0.94 in the case of PMN-PT), which inherently contributes to better acoustic impedance matching between transducers and water, together with higher sensitivity and improved image resolution [79].

Apart from the above conventional piezoelectric materials and their composites, new materials and technologies are emerging in PA/US endoscopy, including lead free piezoelectric materials [80], micromachine based US transducers (piezoelectric and capacitive micromachined US transducer, PMUT and CMUT) [81-86], and optical based acoustic 
sensing [87]. They have their own unique advantages, but further developments are still required to prove their practical capabilities in PA/US endoscopy.

\subsection{Sheath}

A plastic sheath confines the rotating imaging probe to prevent tissue damage. An ideal sheath for PA imaging should be flexible as well as optically and acoustically transparent to minimize the attenuation of the PA signal and artifacts. Iskander-Rizk et al. investigated the optical and acoustic attenuation of various sheath materials [88], including polyethylene (PE), fluorinated ethylene propylene (FEP), Ethylene tetrafluoroethylene (ETFE), Polytetrafluoroethylene (PTFE ), Pebax, OCT sheath, and NIRS sheath. It was found that the NIRS tube exhibits the best performance (optical attenuation: $0.5 \mathrm{~dB}$, acoustic attenuation: $0.3 \mathrm{~dB}$ ). However, the exact material is proprietary information. The second best is $\mathrm{PE}$, whose attenuation of optical and acoustic signal are $1.5 \mathrm{~dB}$ and $1.2 \mathrm{~dB}$, respectively. Cao et al. [89] also tested a series of sheath materials, including FEP, PTFE, polyimide (PI), PE, and polyurethane (PU), to quantify the transmission efficiency of PA and US signals as well as induced PA and US artifacts, as shown in Figure 5. Among them, PEP, PTEF and PI were excluded due to the strong US artifacts. Both PE and PU show better acoustic performance; however, PU exhibits a larger PA transmission efficiency and smaller PA artifacts.

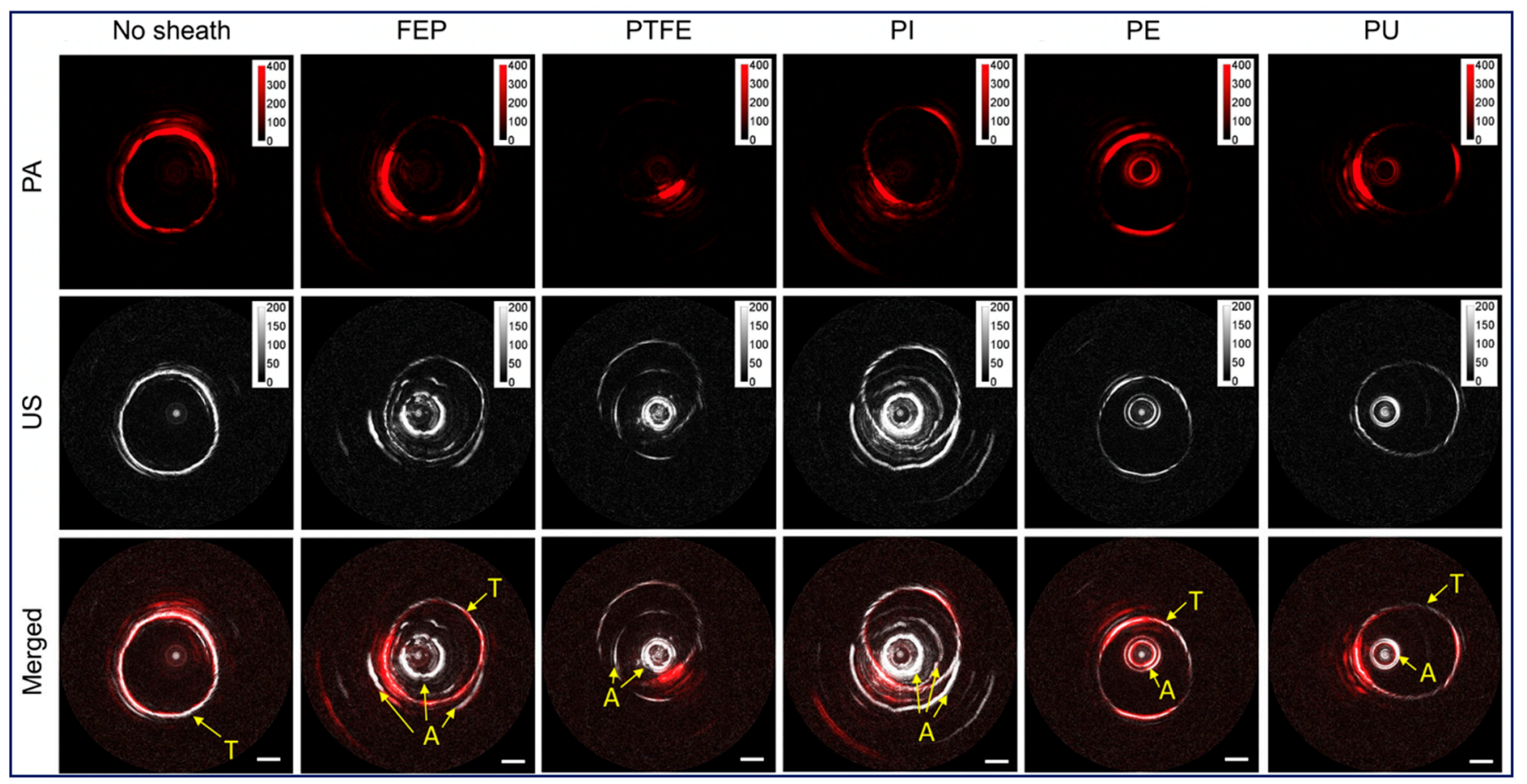

Figure 5. Sheath performance. Adapted from [89]. PE, polyethylene. FEP, fluorinated ethylene propylene. PTFE, polytetrafluoroethylene. PI, polyimide. PU, polyurethane. A, induced artifact from sheath. T, imaging target.

\section{Application}

Endoscopic PA imaging has been investigated in a wide variety of applications, including the characterization of atherosclerosis, GI pathologies, and prostate cancer $[9,22-25,37,46,47,54,60,90,91]$. This review is mainly focused on cardiovascular and GI tract PA imaging, in which representative applications are discussed.

\subsection{GI Tract Application}

A colonoscopy (i.e., white light endoscopy) is commonly used to evaluate gastrointestinal symptoms. For further diagnosis, physicians also need to excise a small section of suspicious lesions through a colonoscopy for biopsy. While being the standard diagnostic method, a colonoscopy provides only surface morphology of the rectal wall and 
cannot resolve the layered architecture and functional information. In addition, diagnostic accuracy is limited by sample number and size [92-94]. To address the limitations of a conventional colonoscopy, endoscopic US, OCT, NIRF, and multiphoton have been applied in the GI tract to visualize the layered architecture and microvasculature, detect early stage disease, and assess treatment response with exogenous optical contrast agents, which represents a significant step toward noninvasive comprehensive characterization of GI disease [3,38,95-111]. However, one of the key parameters, $\mathrm{SO}_{2}$ saturation, is still lacking. Additionally, contrast agent is necessary during NIRF imaging, which increases invasiveness and may raise safety concerns.

Endoscopic PA imaging provides molecular contrast with depth information, which allows for the simultaneous visualization of structural and functional information. It has attracted intensive research interest and been applied in GI tract for characterization of diseases in GI tract by mapping vasculature, measuring $\mathrm{SO}_{2}$ saturation, and evaluating elasticity. Yang et al. [47] present a high-resolution endoscopic PA system, which enables visualization of vasculature with a much finer resolution of $10 \mu \mathrm{m}$ and an imaging speed of $2 \mathrm{~Hz}$, as shown in Figure 6a. However, imaging speed is main limitation for clinical application. To achieve real time imaging, Li et al. [27] developed a high speed PA imaging system, which is able to perform PA and US imaging simultaneously with an imaging speed up to $50 \mathrm{~Hz}$. Nevertheless, the lateral resolution is about $\sim 300 \mu \mathrm{m}$, which makes it difficult to identify microvascular systems clearly. To obtain functional information about the GI tract, Yang et al. [37] demonstrated a functional PA and US system by applying an excitation of multiple wavelengths, which allows the simultaneous visualization of vasculature, $\mathrm{SO}_{2}$ level, and the morphology of a rat colon, as shown in Figure 6c. This is the first demonstration of measuring $\mathrm{SO}_{2}$ in the $\mathrm{GI}$ tract and represents a significant step toward comprehensive diagnosis, but the imaging speed is still a main concern for clinical translation of this technology. Jin et al. further extend PA imaging to perform elastography using phase sensitive PA imaging [46], in which tissue biomechanics and morphology can be obtained by detecting the PA phase and PA amplitude information, respectively. Ex vivo experiments were performed to demonstrate the feasibility of the proposed system, as shown in Figure 6d. The accuracy and speed of imaging still need to be further improved for in vivo application. To realize noncontact endoscopic imaging, Ansari et al. demonstrated an all optical endoscopic imaging probe with a Fabry-Pérot (FP) polymer-film as the US sensor [13], which can provide high resolution 3D vasculature of mouse abdominal skin. This approach avoids the need for separate and bulky detectors, providing more flexibility. However, the shallow penetration depth $(\sim 2 \mathrm{~mm})$ and long acquisition time (25 min for two images) inhibit clinical application. 

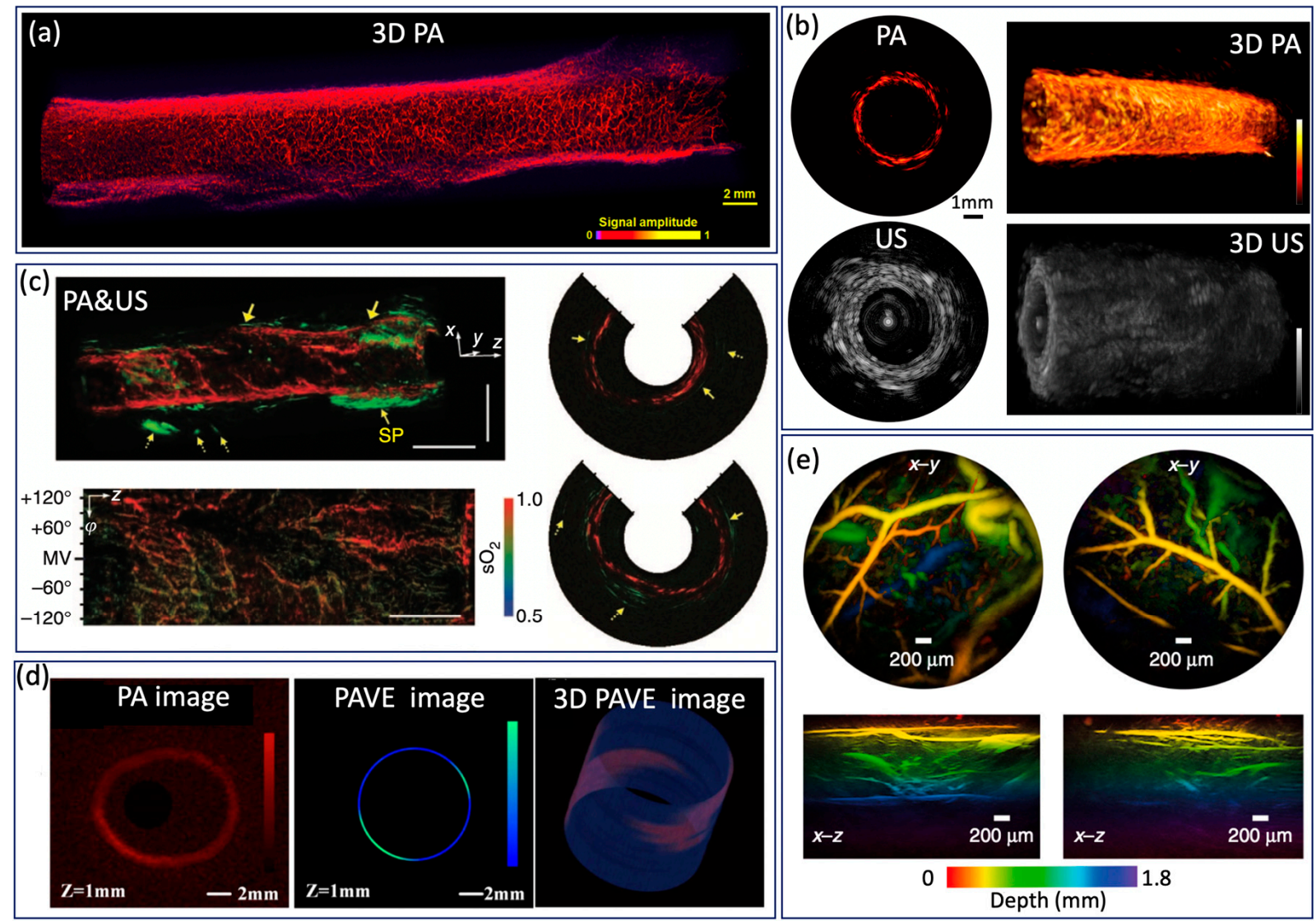

Figure 6. (a) Optical resolution PA image from a rat colorectum. Adapted from [47]. (b) High speed PA image from a rat rectum. Adapted from [27]. (c) $\mathrm{SO}_{2}$ levels of a rat colon. Adapted from [37]. (d) PA image and PAVE image of a severe reflux esophagitis from a rabbit. Adapted from [46]. (e) PA image of mouse abdominal skin microvasculature. Adapted from [13].

\subsection{Intravascular Application}

In clinical practice, computed tomographic angiography is routinely performed to identify the stenotic region caused by plaque formation via visualization of coronary arteries in two dimensions; however, it lacks the spatial resolution necessary to resolve tissue-level information of the arterial wall, hence the inadequacy in studying vulnerable plaques [112-114]. The development of modern intravascular imaging techniques aims to address this limitation in identifying vulnerable plaques. Intervascular US (IVUS) and OCT (IVOCT) are currently the most significant clinical adaptations. The large penetration depth of IVUS enables full depth visualization of the coronary lumen, blood vessel wall, and atherosclerotic plaque formation, and therefore has been routinely utilized in clinical practices since the early 2000s [115-118]. IVOCT, which has high resolution of 1-15 $\mu \mathrm{m}$, has the capability to measure fibrous cap thickness $[119,120]$. Nevertheless, IVOCT suffers from a shallow penetration depth and has limited utility in accessing larger plaques, and IVUS lacks the resolution for visualizing microstructure. In addition, both IVUS and IVOCT have limited sensitivity for studying chemical composition and quantifying tissue mechanical properties, which are key indicators of plaque vulnerability [121-124]. To obtain the chemical composition of a plaque, intravascular NIRF and NIRS capable of providing molecular contrast with high sensitivity have been applied to characterize the intralesion lipid content, but these techniques lack depth information [125-129]. Conversely, intravascular PA (IVPA) imaging is able to provide extremely high molecular contrast while maintaining the superior imaging depth of US imaging [50,130,131], which can map blood vessel wall and lipid content simultaneously. Intravascular imaging of atherosclerotic specimens from cadaver and animal models has been demonstrated $[9,11]$. Li et al. reported a $532 \mathrm{~nm}$ intravascular imaging system and imaged a normal rabbit aorta [53]. Figure 7a 
shows US, PA, fused images, and an H\&E histology photo, in which different layers (intima, media, and adventitia) of a vessel wall can be identified. To map the lipid component in plaque, several research teams investigated IVPA imaging with excitation wavelengths of 1210 and $1720 \mathrm{~nm}[9,22-25,54,60,91]$. According to the absorption spectrum of lipids, $1720 \mathrm{~nm}$ is considered the optimal wavelength for IVPA imaging because of the higher absorption coefficient and longer penetration depth. Piao et al. reported an intravascular PA imaging system based on a 1.7 micron pulsed laser and imaged an atherosclerotic rabbit aorta, as shown in Figure 7b [24]. In the image, PA signal was observed at the upper left and lower region (encircled), which indicates the presence of lipid. In addition, the intimal thickening can be found in the corresponding locations (encircled) in the IVUS image, which agrees well with the PA image. The advantage of the $1720 \mathrm{~nm}$ band for the IVPA imaging of lipids was also confirmed by Wang et al., who reported a threefold enhancement of the IVPA signal from excitation at $1720 \mathrm{~nm}$ vs. excitation at $1210 \mathrm{~nm}$, and demonstrated that IVPA has the capability of imaging lipids through luminal blood using the $1720 \mathrm{~nm}$ wavelength [91], as shown in Figure 7c. Considering that lipid within atherosclerotic plaques is the key determining factor, Jansen et al. reported a spectroscopic IVPA imaging system to identify and distinguish atherosclerotic lipid and peri-adventitial lipid. Based on a cholesterol PA spectrum, as a reference for atherosclerotic lipids, and a peri-adventitial reference spectrum, atherosclerotic and peri-adventitial lipids can be well distinguished using correlation with six wavelengths, as shown in Figure 7d. With three well chosen wavelengths, a satisfactory distinction can be achieved. However, with only two wavelengths, atherosclerotic and peri-adventitial lipids can be identified but not distinguished. Additionally, Wang et al. reported a thermal IVPA imaging system, which is able to distinguish lipid types using different temperature dependent PA responses from lipid in plaques and lipid in periadventitial tissue [132], as shown in Figure 7e, where atherosclerotic lipid was mapped overlaid on a US image. In addition to visualizing tissue composition, Wang et al. extended IVPA to quantify vessel elasticity through the PA phase, where a smaller elastic modulus can be found in the plaque region, as shown in Figure $7 \mathrm{f}$ [56]. Elasticity of vessel wall is one of the key indicators, as the stress in a fibrous cap is altered by its thickness and macrophage infiltration, which provides additional information for comprehensive characterization of plaque. Furthermore, Yeager et al. investigated IVPA imaging of exogenously labeled atherosclerotic plaque through luminal blood using gold nanorods conjugated with PEG [133]. The nanoparticle is able to label sites of atherosclerosis as well as microphases, as shown in Figure $7 \mathrm{~g}$. The addition of a exogenous contrast agent can further improve sensitivity, and make imaging through blood possible. Currently, the main limitation of the above mentioned IVPA system is the slow imaging speed caused by the slow repetition rate of the pulsed laser. In 2017, Wu et al. improved the imaging speed by adopting a $5 \mathrm{kHz}$ OPO laser, but they had to apply heavy water to enhance the SNR due to the small pulse energy [25]. A pulsed laser that can provide sufficient pulse energy as well as a fast repetition rate is necessary for the clinical translation of IVPA. 

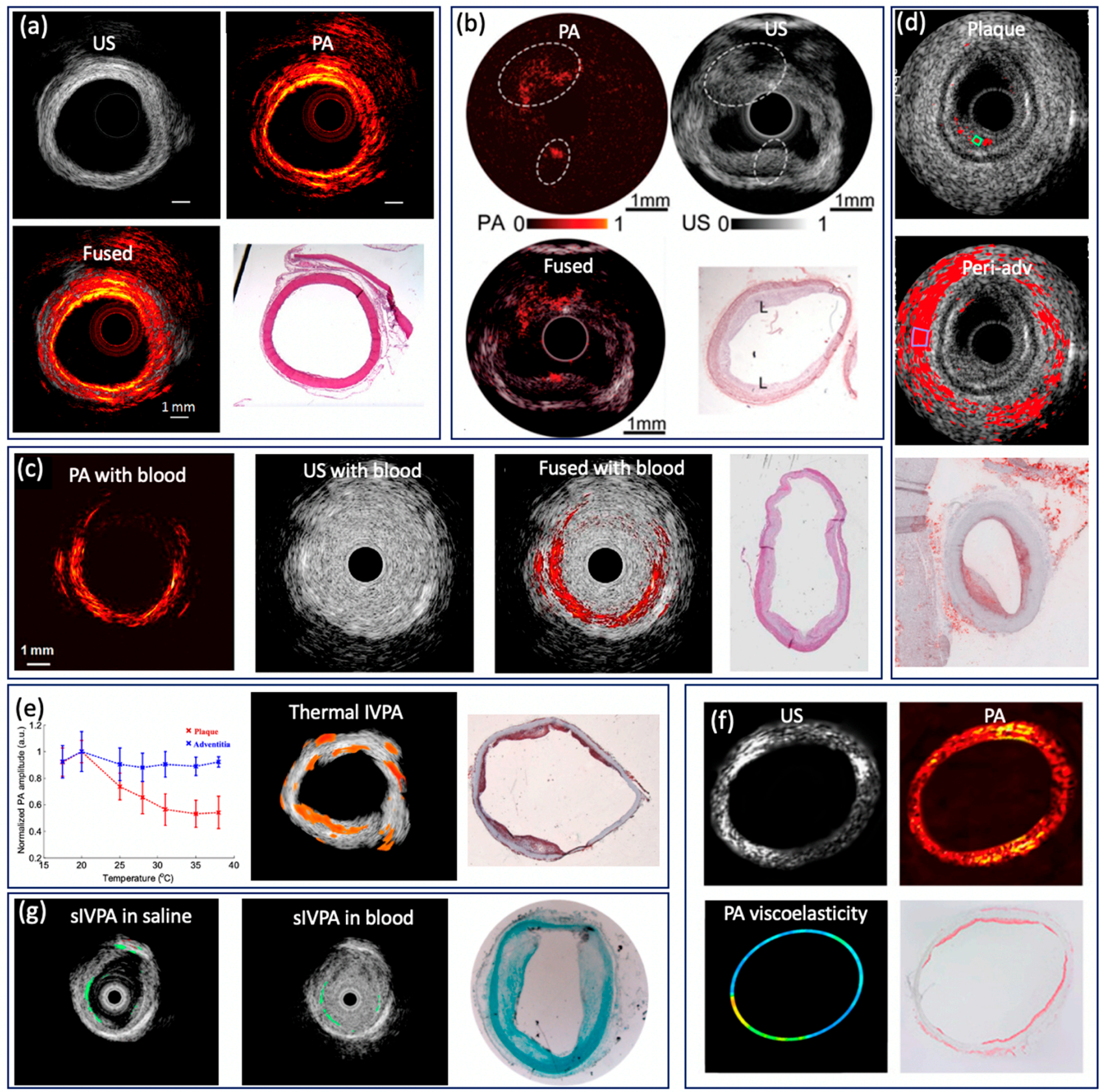

Figure 7. (a) PA/US image of rabbit aorta based on $532 \mathrm{~nm}$ pulsed laser. Adapted from [53]. (b) PA/US image of rabbit aorta based $1725 \mathrm{~nm}$ pulsed laser. Adapted from [24]. (c) IVPA/IVUS imaging of atherosclerotic rabbit aorta in the human RBCs solution. Adapted from [91]. (d) Atherosclerotic and peri-adventitial lipids map from human coronary artery based on wavelength correlation. Adapted from [35]. (e) Thermal IVPA images of atherosclerotic rabbit aorta. Adapted from [132]. (f) PA, US, elasticity images of rabbit aorta. Adapted from [56]. (g) Spectroscopic IVPA image of gold nanorods. Adapted from [133].

\section{Discussion}

Endoscopic PA imaging provides functional and molecular information, thereby supplementing conventional endoscope to obtain more comprehensive information. The feasibility has been demonstrated in cadaver tissue and animal model. Although rapid progress has been made, most of the work is still in its preclinical stage. More efforts need to be made to further facilitate clinical translation.

PA signal detection plays an important role in achieving high quality PA images. Although better detection efficiency can be achieved using an imaging probe with coaxial 
configuration, the probe size will be increased due to the introduction of the ring-shaped transducer. To address this issue, a transparent US transducer could be a possible solution and allow for coaxial alignment without increasing probe outer diameter. $\mathrm{LiNbO}_{3}$ crystals are commonly used in transparent US transducers, and applications for these transducers in microscopic and endoscopic PA imaging have been demonstrated by several research groups [134-136]. However, the sensitivity of $\mathrm{LiNbO}_{3}$ based US transducers are limited due to their relatively low piezoelectric coefficient and electromechanical coupling factor. In 2020, Qiu et al. [137] fabricated a transparent PMN-PT crystal using an alternating-current electric field. These crystals exhibit near perfect transparency, an ultrahigh piezoelectric coefficient, an excellent electromechanical coupling factor, and a large electro-optical coefficient. Dangi et al. [138] applied this transparent PMN-PT based US transducer in PA imaging. This high sensitivity transparent US transducer could provide more flexibility of probe design, further facilitating the translation of this endoscopic PA imaging technology to clinical use. Furthermore, FP US transducers show great potential in endoscopic PA imaging. In addition to more design flexibility, FB US transducers are free of electromagnetic interference and perform noncontact imaging, which allows for more applications, such as airway PA imaging.

In addition to molecular contrast, functional information is essential for the characterization of target tissue. Since the first demonstration of PA imaging in biomedical imaging in the mid 1990s, several functional extensions of PA imaging have been investigated, including spectroscopic imaging, elasticity, Doppler flowmetry [139,140], and thermometry. Both spectroscopic PA imaging and PA elastography have been applied in endoscopic imaging to identify and quantify specific tissue chromophores as well as elasticity evaluation. PA Doppler flowmetry, based on the Doppler principle, was proposed to measure blood flow velocity and validated in a phantom experiment. Introducing PA Doppler flowmetry in endoscopic PA imaging would be useful because blood velocity is a key physiology parameter of tissue metabolism, which can be used to characterize GI tumors as well as monitoring therapeutic responses. Furthermore, as the PA signal is proportional to the Grüneisen coefficient, that is, temperature dependence, PA imaging has been investigated as a way to map temperature distribution in tissue [141-143]. The addition of PA thermometry in endoscopic imaging will allow for the real time, noninvasive temperature monitoring of energy based treatments.

Integrating PA imaging with other contemporary imaging modalities would provide more comprehensive assessments; this benefit will speed up clinical translation. Dai et al. [144] and Leng et al. [145] reported a trimodality intravascular imaging system which combined PA, US, and OCT for the characterization of atherosclerosis. The addition of OCT contributes to the identification of thin fibrous caps. Furthermore, Zhang et al. [146] developed a combined IVPA and autofluorescence imaging system, which is able to detect lipid core and intraplaque hemorrhage simultaneously. Optical coherence elastography (OCE) can resolve a localized displacement in subnanometers and is therefore ideal for studying the elasticity of biological tissue, which can be incorporated into PA imaging to enable simultaneous visualization of morphology, molecular contrast, and biomechanical properties to further improve diagnostic outcome $[121,147,148]$.

With continuous advancement, PA will be a powerful tool that provides a quantitative means to benchmark and evaluate therapies. Subsurface architecture, vasculature morphology, and $\mathrm{SO}_{2}$ saturation are key parameters for the evaluation of GI disease, so endoscopic PA can be used for early detection and staging of GI cancer, as well as monitoring and guiding surgery (such as the identification of tumour margins). With exogenous optical contrast agents, endoscopic PA allows for real time monitoring of the therapeutic response of drugs. For intravascular imaging, the addition of molecular information and elasticity would significantly improve the accuracy of identifying vulnerable plaque. 


\section{Conclusions}

In summary, endoscopic PA imaging provides noninvasive techniques for quantitative and dynamic evaluation of tissue physiology and pathophysiology in vivo. With different probe configurations and functional extensions, endoscopic PA imaging will find a broad range of clinical applications.

Author Contributions: Y.L. and Z.C.: writing—original draft preparation; G.L. and Q.Z.: writing-Ultrasound Transducer section. All authors have read and agreed to the published version of the manuscript.

Funding: This work was supported by grant from the National Institutes of Health (R01EY-026091, R01EY-028662, R01HL-125084, R01HL-127271, R01EB-030024), and the American Heart Association (20POST35200050).

Institutional Review Board Statement: Not applicable.

Informed Consent Statement: Not applicable.

Conflicts of Interest: Zhongping Chen has a financial interest in OCT Medical Imaging, Inc., which, however, did not support this work.

\section{References}

1. Gora, M.J.; Suter, M.J.; Tearney, G.J.; Li, X. Endoscopic optical coherence tomography: Technologies and clinical applications [Invited]. Biomed. Opt. Express 2017, 8, 2405-2444. [CrossRef]

2. Rosch, T. Endoscopic ultrasonography: Imaging and beyond. Gut 2003, 52, 1220-1226. [CrossRef] [PubMed]

3. Ducourthial, G.; Leclerc, P.; Mansuryan, T.; Fabert, M.; Brevier, J.; Habert, R.; Braud, F.; Batrin, R.; Vever-Bizet, C.; Bourg-Heckly, G.; et al. Development of a real-time flexible multiphoton microendoscope for label-free imaging in a live animal. Sci. Rep. 2015, 5, 18303. [CrossRef]

4. Wang, X.; Pang, Y.; Ku, G.; Xie, X.; Stoica, G.; Wang, L. Noninvasive laser-induced photoacoustic tomography for structural and functional in vivo imaging of the brain. Nat. Biotechnol. 2003, 21, 803-806. [CrossRef] [PubMed]

5. Brecht, H.-P.F.; Su, R.; Fronheiser, M.P.; Ermilov, S.A.; Conjusteau, A.; Oraevsky, A.A. Whole-body three-dimensional optoacoustic tomography system for small animals. J. Biomed. Opt. 2009, 14, 064007. [CrossRef] [PubMed]

6. Yang, J.-M.; Maslov, K.; Yang, H.-C.; Zhou, Q.; Shung, K.K.; Wang, L. Photoacoustic endoscopy. Opt. Lett. 2009, $34,1591-1593$. [CrossRef] [PubMed]

7. Wang, B.; Su, J.L.; Amirian, J.; Litovsky, S.H.; Smalling, R.; Emelianov, S. Detection of lipid in atherosclerotic vessels using ultrasound-guided spectroscopic intravascular photoacoustic imaging. Opt. Express 2010, 18, 4889-4897. [CrossRef] [PubMed]

8. Sethuraman, S.; Aglyamov, S.R.; Amirian, J.H.; Smalling, R.W.; Emelianov, S.Y. Intravascular photoacoustic imaging using an IVUS imaging catheter. IEEE Trans. Ultrason. Ferroelectr. Freq. Control 2007, 54, 978-986. [CrossRef] [PubMed]

9. Jansen, K.; Van Der Steen, A.F.W.; Van Beusekom, H.; Oosterhuis, J.; van Soest, G. Intravascular photoacoustic imaging of human coronary atherosclerosis. Opt. Lett. 2011, 36, 597-599. [CrossRef] [PubMed]

10. Wang, H.W.; Chai, N.; Wang, P.; Hu, S.; Dou, W.; Umulis, D.; Wang, L.V.; Sturek, M.; Lucht, R.; Cheng, J.X. Label-free bond-selective imaging by listening to vibrationally excited molecules. Phys. Rev. Lett. 2011, 106, 238106. [CrossRef] [PubMed]

11. Wei, W.; Li, X.; Zhou, Q.; Shung, K.K.; Chen, Z. Integrated ultrasound and photoacoustic probe for co-registered intravascular imaging. J. Biomed. Opt. 2011, 16, 106001. [CrossRef] [PubMed]

12. Wang, P.; Wang, H.-W.; Sturek, M.; Cheng, J.-X. Bond-selective imaging of deep tissue through the optical window between 1600 and $1850 \mathrm{~nm}$. J. Biophotonics 2012, 5, 25-32. [CrossRef] [PubMed]

13. Ansari, R.; Zhang, E.Z.; Desjardins, A.E.; Beard, P.C. All-optical forward-viewing photoacoustic probe for high-resolution 3D endoscopy. Light. Sci. Appl. 2018, 7, 1-9. [CrossRef] [PubMed]

14. Mathews, S.J.; Little, C.; Loder, C.D.; Rakhit, R.D.; Xia, W.; Zhang, E.Z.; Beard, P.C.; Finlay, M.; Desjardins, A.E. All-optical dual photoacoustic and optical coherence tomography intravascular probe. Photoacoustics 2018, 11, 65-70. [CrossRef]

15. Wissmeyer, G.; Pleitez, M.A.; Rosenthal, A.; Ntziachristos, V. Looking at sound: Optoacoustics with all-optical ultrasound detection. Light. Sci. Appl. 2018, 7, 53. [CrossRef] [PubMed]

16. Chen, Z.; Yang, S.; Wang, Y.; Xing, D. Noncontact broadband all-optical photoacoustic microscopy based on a low-coherence interferometer. Appl. Phys. Lett. 2015, 106, 043701. [CrossRef]

17. Guo, Z.; Li, G.; Chen, S.-L. Miniature probe for all-optical double gradient-index lenses photoacoustic microscopy. J. Biophotonics 2018, 11, e201800147. [CrossRef] [PubMed]

18. Li, G.; Guo, S.L.Z. Chen, Miniature all-optical probe for large synthetic aperture photoacoustic-ultrasound imaging. Opt. Express 2017, 25, 25023-25035. [CrossRef] [PubMed]

19. Sheaff, C.; Ashkenazi, S. An all-optical thin-film high-frequency ultrasound transducer. In Proceedings of the 2011 IEEE International Ultrasonics Symposium, Orlando, FL, USA, 18-21 October 2011; pp. 1944-1947. [CrossRef] 
20. Preisser, S.; Rohringer, W.; Liu, M.; Kollmann, C.; Zotter, S.; Fischer, B.; Drexler, W. All-optical highly sensitive akinetic sensor for ultrasound detection and photoacoustic imaging. Biomed. Opt. Express 2016, 7, 4171-4186. [CrossRef] [PubMed]

21. Hui, J.; Yu, Q.; Ma, T.; Wang, P.; Cao, Y.; Bruning, R.S.; Qu, Y.; Chen, Z.; Zhou, Q.; Sturek, M.; et al. High-speed intravascular photoacoustic imaging at $1.7 \mu \mathrm{m}$ with a KTP-based OPO. Biomed. Opt. Express 2015, 6, 4557-4566. [CrossRef] [PubMed]

22. Li, Y.; Gong, X.; Liu, C.; Lin, R.; Hau, W.; Bai, X.; Song, L. High-speed intravascular spectroscopic photoacoustic imaging at 1000 A-lines per second with a 0.9-mm diameter catheter. J. Biomed. Opt. 2015, 20, 065006. [CrossRef] [PubMed]

23. Wang, P.; Ma, T.; Slipchenko, M.N.; Liang, S.; Hui, J.; Shung, K.K.; Roy, S.; Sturek, M.; Zhou, Q.; Chen, Z.; et al. High-speed Intravascular Photoacoustic Imaging of Lipid-laden Atherosclerotic Plaque Enabled by a 2-kHz Barium Nitrite Raman Laser. Sci. Rep. 2014, 4, 6889. [CrossRef] [PubMed]

24. Piao, Z.; Ma, T.; Li, J.; Wiedmann, M.T.; Huang, S.; Yu, M.; Shung, K.K.; Zhou, Q.; Kim, C.-S.; Chen, Z. High speed intravascular photoacoustic imaging with fast optical parametric oscillator laser at $1.7 \mu \mathrm{m}$. Appl. Phys. Lett. 2015, 107, 083701. [CrossRef]

25. Wu, M.; Springeling, G.; Lovrak, M.; Mastik, F.; Iskander-Rizk, S.; Wang, T.; Van Beusekom, H.M.M.; Van Der Steen, A.F.W.; Van Soest, G. Real-time volumetric lipid imaging in vivo by intravascular photoacoustics at 20 frames per second. Biomed. Opt. Express 2017, 8, 943-953. [CrossRef]

26. Jansen, K.; Wu, M.; van der Steen, A.F.; van Soest, G. Photoacoustic imaging of human coronary atherosclerosis in two spectral bands. Photoacoustics 2014, 2, 12-20. [CrossRef]

27. Li, Y.; Zhu, Z.; Jing, J.C.; Chen, J.J.; Heidari, A.E.; He, Y.; Zhu, J.; Ma, T.; Yu, M.; Zhou, Q.; et al. High-Speed Integrated Endoscopic Photoacoustic and Ultrasound Imaging System. IEEE J. Sel. Top. Quantum Electron. 2019, 25, 1-5. [CrossRef] [PubMed]

28. Li, Y.; Lin, R.; Liu, C.; Chen, J.; Liu, H.; Zheng, R.; Gong, X.; Song, L. In vivo photoacoustic/ultrasonic dual-modality endoscopy with a miniaturized full field-of-view catheter. J. Biophotonics 2018, 11, e201800034. [CrossRef] [PubMed]

29. Li, Y.; Lu, G.; Chen, J.; Jing, J.C.; Huo, T.; Chen, R.; Jiang, L.; Zhou, Q.; Chen, Z. PMN-PT/Epoxy 1-3 composite based ultrasonic transducer for dual-modality photoacoustic and ultrasound endoscopy. Photoacoustics 2019, 15, 100138. [CrossRef] [PubMed]

30. Roggan, A.; Friebel, M.; Dörschel, K.; Hahn, A.; Müller, G. Optical Properties of Circulating Human Blood in the Wavelength Range 400-2500 nm. J. Biomed. Opt. 1999, 4, 36-46. [CrossRef] [PubMed]

31. Anderson, R.R.; Farinelli, W.; Laubach, H.; Manstein, D.; Yaroslavsky, A.N.; Gubeli, J.; Jordan, K.; Neil, G.R.; Shinn, M.; Chandler, W.; et al. Selective photothermolysis of lipid-rich tissues: A free electron laser study. Lasers Surg. Med. 2006, 38, 913-919. [CrossRef]

32. Tsai, C.-L.; Chen, J.-C.; Wang, W.-J. Near-infrared Absorption Property of Biological Soft Tissue Constituents. J. Med. Biol. Eng. 2001, 21, 7-14.

33. Available online: http:/ / omlc.ogi.edu/spectra (accessed on 21 April 2021).

34. Jansen, K.; Van Der Steen, A.F.W.; Wu, M.; Van Beusekom, H.M.M.; Springeling, G.; Li, X.; Zhou, Q.; Shung, K.K.; De Kleijn, D.P.V.; van Soest, G. Spectroscopic intravascular photoacoustic imaging of lipids in atherosclerosis. J. Biomed. Opt. 2014, 19, 026006. [CrossRef] [PubMed]

35. Jansen, K.; Wu, M.; van der Steen, A.F.; van Soest, G. Lipid detection in atherosclerotic human coronaries by spectroscopic intravascular photoacoustic imaging. Opt. Express 2013, 21, 21472-21484. [CrossRef] [PubMed]

36. Yao, J.; Maslov, K.; Zhang, Y.S.; Xia, Y.; Wang, L. Label-free oxygen-metabolic photoacoustic microscopy in vivo. J. Biomed. Opt. 2011, 16, 076003. [CrossRef]

37. Yang, J.-M.; Favazza, C.; Chen, R.; Yao, J.; Cai, X.; Maslov, K.; Zhou, Q.; Shung, K.K.; Wang, L. Simultaneous functional photoacoustic and ultrasonic endoscopy of internal organs in vivo. Nat. Med. 2012, 18, 1297-1302. [CrossRef]

38. Li, Y.; Jing, J.; Qu, Y.; Miao, Y.; Zhang, B.; Ma, T.; Yu, M.; Zhou, Q.; Chen, Z. Fully integrated optical coherence tomography, ultrasound, and indocyanine green-based fluorescence tri-modality system for intravascular imaging. Biomed. Opt. Express 2017, 8, 1036-1044. [CrossRef]

39. Vinegoni, C.; Botnaru, I.; Aikawa, E.; Calfon, M.A.; Iwamoto, Y.; Folco, E.J.; Ntziachristos, V.; Weissleder, R.; Libby, P.; Jaffer, F.A. Indocyanine Green Enables Near-Infrared Fluorescence Imaging of Lipid-Rich, Inflamed Atherosclerotic Plaques. Sci. Transl. Med. 2011, 3, 84ra45. [CrossRef] [PubMed]

40. Zhou, J.; Jokerst, J.V. Photoacoustic imaging with fiber optic technology: A review. Photoacoustics 2020, 20, 100211. [CrossRef]

41. Guo, H.; Li, Y.; Qi, W.; Xi, L. Photoacoustic endoscopy: A progress review. J. Biophotonics 2020, 13, e202000217. [CrossRef]

42. Yang, J.-M.; Chen, R.; Favazza, C.; Yao, J.; Li, C.; Hu, Z.; Zhou, Q.; Shung, K.K.; Wang, L. A 25-mm diameter probe for photoacoustic and ultrasonic endoscopy. Opt. Express 2012, 20, 23944-23953. [CrossRef] [PubMed]

43. He, H.; Stylogiannis, A.; Afshari, P.; Wiedemann, T.; Steiger, K.; Buehler, A.; Zakian, C.; Ntziachristos, V. Capsule optoacoustic endoscopy for esophageal imaging. J. Biophotonics 2019, 12, e201800439. [CrossRef] [PubMed]

44. Li, X.; Xiong, K.; Yang, S. Large-depth-of-field optical-resolution colorectal photoacoustic endoscope. Appl. Phys. Lett. 2019, 114, 163703. [CrossRef]

45. Xiong, K.; Yang, S.; Li, X.; Xing, D. Autofocusing optical-resolution photoacoustic endoscopy. Opt. Lett. 2018, 43, 1846-1849. [CrossRef]

46. Jin, D.; Yang, F.; Chen, Z.; Yang, S.; Xing, D. Biomechanical and morphological multi-parameter photoacoustic endoscope for identification of early esophageal disease. Appl. Phys. Lett. 2017, 111, 103703. [CrossRef]

47. Yang, J.-M.; Li, C.; Cheng-Hung, Y.; Rao, B.; Yao, J.; Yeh, C.-H.; Danielli, A.; Maslov, K.; Zhou, Q.; Shung, K.K.; et al. Opticalresolution photoacoustic endomicroscopy in vivo. Biomed. Opt. Express 2015, 6, 918-932. [CrossRef] 
48. Liu, N.; Yang, S.; Xing, D. Photoacoustic and hyperspectral dual-modality endoscope. Opt. Lett. 2018, 43, 138-141. [CrossRef] [PubMed]

49. Basij, M.; Yan, Y.; Alshahrani, S.S.; Helmi, H.; Burton, T.K.; Burmeister, J.W.; Dominello, M.M.; Winer, I.S.; Mehrmohammadi, M. Miniaturized phased-array ultrasound and photoacoustic endoscopic imaging system. Photoacoustics 2019, 15, 100139. [CrossRef]

50. Yuan, Y.; Yang, S.; Xing, D. Preclinical photoacoustic imaging endoscope based on acousto-optic coaxial system using ring transducer array. Opt. Lett. 2010, 35, 2266-2268. [CrossRef]

51. Guo, H.; Song, C.; Xie, H.; Xi, L. Photoacoustic endomicroscopy based on a MEMS scanning mirror. Opt. Lett. 2017, 42, 4615-4618. [CrossRef]

52. Ji, X.; Xiong, K.; Yang, S.; Xing, D. Intravascular confocal photoacoustic endoscope with dual-element ultrasonic transducer. Opt. Express 2015, 23, 9130-9136. [CrossRef]

53. Li, X.; Wei, W.; Zhou, Q.; Shung, K.K.; Chen, Z. Intravascular photoacoustic imaging at 35 and 80 MHz. J. Biomed. Opt. 2012, 17, 1060051. [CrossRef]

54. Wang, B.; Karpiouk, A.; Yeager, D.; Amirian, J.; Litovsky, S.; Smalling, R.; Emelianov, S. In vivo Intravascular Ultrasound-guided Photoacoustic Imaging of Lipid in Plaques Using an Animal Model of Atherosclerosis. Ultrasound Med. Biol. 2012, 38, $2098-2103$. [CrossRef] [PubMed]

55. Zhang, J.; Yang, S.; Ji, X.; Zhou, Q.; Xing, D. Characterization of lipid-rich aortic plaques by intravascular photoacoustic tomography: Ex vivo and in vivo validation in a rabbit atherosclerosis model with histologic correlation. J. Am. Coll. Cardiol. 2014, 64, 385-390. [CrossRef]

56. Wang, P.; Chen, Z.; Yang, F.; Yang, S.; Xing, D. Intravascular tri-modality system: Combined ultrasound, photoacoustic, and elasticity imaging. Appl. Phys. Lett. 2018, 113, 253701. [CrossRef]

57. Xie, Z.; Shu, C.; Yang, D.; Chen, H.; Chen, C.; Dai, G.; Lam, K.H.; Zhang, J.; Wang, X.; Sheng, Z.; et al. In vivo intravascular photoacoustic imaging at a high speed of 100 frames per second. Biomed. Opt. Express 2020, 11, 6721-6731. [CrossRef] [PubMed]

58. Lei, P.; Wen, X.; Wang, L.; Zhang, P.; Yang, S. Ultrafine intravascular photoacoustic endoscope with a 07 mm diameter probe. Opt. Lett. 2019, 44, 5406-5409. [CrossRef]

59. Bai, X.; Gong, X.; Hau, W.; Lin, R.; Zheng, J.; Liu, C.; Zeng, C.; Zou, X.; Zheng, H.; Song, L. Intravascular Optical-Resolution Photoacoustic Tomography with a $1.1 \mathrm{~mm}$ Diameter Catheter. PLoS ONE 2014, 9, e92463. [CrossRef]

60. Hui, J.; Cao, Y.; Zhang, Y.; Kole, A.; Wang, P.; Yu, G.; Eakins, G.; Sturek, M.; Chen, W.; Cheng, J.-X. Real-time intravascular photoacoustic-ultrasound imaging of lipid-laden plaque in human coronary artery at 16 frames per second. Sci. Rep. 2017, 7, 1417. [CrossRef] [PubMed]

61. Xiong, K.; Wang, W.; Guo, T.; Yuan, Z.; Yang, S. Shape-adapting panoramic photoacoustic endomicroscopy. Opt. Lett. 2019, 44, 2681-2684. [CrossRef]

62. Vanderlaan, D.; Karpiouk, A.B.; Yeager, D.; Emelianov, S. Real-Time Intravascular Ultrasound and Photoacoustic Imaging. IEEE Trans. Ultrason. Ferroelectr. Freq. Control 2017, 64, 141-149. [CrossRef]

63. Yang, J.-M.; Li, C.; Chen, R.; Zhou, Q.; Shung, K.K.; Wang, L. Catheter-based photoacoustic endoscope. J. Biomed. Opt. 2014, 19, 066001. [CrossRef] [PubMed]

64. Qu, Y.; Li, C.; Shi, J.; Chen, R.; Xu, S.; Rafsanjani, H.; Maslov, K.; Krigman, H.; Garvey, L.; Hu, P.; et al. Transvaginal fast-scanning optical-resolution photoacoustic endoscopy. J. Biomed. Opt. 2018, 23, 121617. [CrossRef]

65. Dong, B.; Chen, S.; Zhang, Z.; Sun, C.; Zhang, H.F. Photoacoustic probe using a microring resonator ultrasonic sensor for endoscopic applications. Opt. Lett. 2014, 39, 4372-4375. [CrossRef]

66. Edward, Z.Z.; Paul, C.B. A miniature all-optical photoacoustic imaging probe. In Proceedings of the Photons Plus Ultrasound: Imaging and Sensing 2011, San Francisco, CA, USA, 28 February 2011.

67. Zhang, Y.; Cao, Y.; Cheng, J.-X. High-resolution photoacoustic endoscope through beam self-cleaning in a graded index fiber. Opt. Lett. 2019, 44, 3841-3844. [CrossRef]

68. Wang, L.; Lei, P.; Wen, X.; Zhang, P.; Yang, S. Tapered fiber-based intravascular photoacoustic endoscopy for high-resolution and deep-penetration imaging of lipid-rich plaque. Opt. Express 2019, 27, 12832-12840. [CrossRef] [PubMed]

69. Karpiouk, A.B.; Wang, B.; Amirian, J.; Smalling, R.W.; Emelianov, S.Y. Feasibility of in vivo intravascular photoacoustic imaging using integrated ultrasound and photoacoustic imaging catheter. J. BioMed. Opt. 2012, 17, 96008. [CrossRef]

70. Cao, Y.; Hui, J.; Kole, A.; Wang, P.; Yu, Q.; Chen, W.; Sturek, M.; Cheng, J.-X. High-sensitivity intravascular photoacoustic imaging of lipid-laden plaque with a collinear catheter design. Sci. Rep. 2016, 6, 25236. [CrossRef]

71. Zhou, Q.; Chen, Z. Multimodality Imaging; Springer: Berlin/Heidelberg, Germany, 2020.

72. Jansen, K. Intravascular Photoacoustics; Erasmus University Rotterdam: Rotterdam, The Netherlands, 2013.

73. Foster, F.; Harasiewicz, K.; Sherar, M. A history of medical and biological imaging with polyvinylidene fluoride (PVDF) transducers. IEEE Trans. Ultrason. Ferroelectr. Freq. Control 2000, 47, 1363-1371. [CrossRef] [PubMed]

74. Yue, W.; Yi-Jian, J. Crystal orientation dependence of piezoelectric properties in $\mathrm{LiNbO}_{3}$ and $\mathrm{LiTaO}_{3}$. Opt. Mater. 2003, 23, 403-408. [CrossRef]

75. Zhou, Q.; Xu, X.; Gottlieb, E.J.; Sun, L.; Cannata, J.M.; Ameri, H.; Humayun, M.S.; Han, P.; Shung, K.K. PMN-PT single crystal, high-frequency ultrasonic needle transducers for pulsed-wave Doppler application. IEEE Trans. Ultrason. Ferroelectr. Freq. Control 2007, 54, 668-675. [CrossRef] 
76. Xiao, J.; Li, Y.; Jin, W.; Peng, K.; Zhu, Z.; Wang, B. Photoacoustic endoscopy with hollow structured lens-focused polyvinylidine fluoride transducer. Appl. Opt. 2016, 55, 2301-2305. [CrossRef]

77. Guo, Q.; Cao, G.Z.; Shen, I.Y. Measurements of Piezoelectric Coefficient d33 of Lead Zirconate Titanate Thin Films Using a Mini Force Hammer. J. Vib. Acoust 2013, 135, 011003. [CrossRef]

78. Kim, K.-B.; Hsu, D.K.; Ahn, B.; Kim, Y.-G.; Barnard, D.J. Fabrication and comparison of PMN-PT single crystal, PZT and PZT-based 1-3 composite ultrasonic transducers for NDE applications. Ultrasonics 2010, 50, 790-797. [CrossRef]

79. Zhou, K.K.S.M.C.F. Piezoelectric materials for high frequency medical imaging applications: A review. J. Electroceramics 2007, 19, 141-147.

80. Zhu, B.; Wei, W.; Li, Y.; Yang, X.; Zhou, Q.; Shung, K. KNN-based single crystal high frequency transducer for intravascular photoacoustic imaging. In Proceedings of the 2017 IEEE International Ultrasonics Symposium (IUS), Washington, DC, USA, 6-9 September 2017.

81. Dangi, A.; Agrawal, S.; Tiwari, S.; Jadhav, S.; Cheng, C.; Datta, G.R.; Troiler-McKinstry, S.; Pratap, R.; Kothapalli, S.-R. Ring PMUT array based miniaturized photoacoustic endoscopy device. In Proceedings of the Photons Plus Ultrasound: Imaging and Sensing 2019, San Francisco, CA, USA, 27 February 2019; Volume 10878, p. 1087811.

82. Wang, H.; Chen, Z.; Yang, H.; Jiang, H.; Xie, H. A Ceramic PZT-Based PMUT Array for Endoscopic Photoacoustic Imaging. J. Microelectromechanical Syst. 2020, 29, 1038-1043. [CrossRef] [PubMed]

83. Wang, H.; Feng, P.X.-L.; Xie, H. A High-Density and Dual-Frequency PMUT Array Based on Thin Ceramic PZT for Endoscopic Photoacoustic Imaging. In Proceedings of the 2021 IEEE 34th International Conference on Micro Electro Mechanical Systems (MEMS), Gainesville, FL, USA, 25-29 January 2021; pp. 891-894.

84. Chan, J.; Zheng, Z.; Bell, K.; Le, M.; Reza, P.H.; Yeow, J.T. Photoacoustic Imaging with Capacitive Micromachined Ultrasound Transducers: Principles and Developments. Sensors 2019, 19, 3617. [CrossRef]

85. Vallet, M.; Varray, F.; Boutet, J.; Dinten, J.-M.; Caliano, G.; Savoia, A.S.; Vray, D. Quantitative comparison of PZT and CMUT probes for photoacoustic imaging: Experimental validation. Photoacoustics 2017, 8, 48-58. [CrossRef]

86. Wang, H.; Ma, Y.; Yang, H.; Jiang, H.; Ding, Y.; Xie, H. MEMS Ultrasound Transducers for Endoscopic Photoacoustic Imaging Applications. Micromachines 2020, 11, 928. [CrossRef]

87. Ansari, R.; Zhang, E.Z.; Desjardins, A.E.; Beard, P.C. Miniature all-optical flexible forward-viewing photoacoustic endoscopy probe for surgical guidance. Opt. Lett. 2020, 45, 6238-6241. [CrossRef]

88. Iskander-Rizk, S.; Wu, M.; Springeling, G.; Mastik, F.; Beurskens, R.H.; van der Steen, A.F.; van Soest, G. Catheter design optimization for practical intravascular photoacoustic imaging (IVPA) of vulnerable plaques. In Proceedings of the Diagnostic and Therapeutic Applications of Light in Cardiology 2018, San Francisco, CA, USA, 14 February 2018.

89. Cao, Y.; Kole, A.; Hui, J.; Zhang, Y.; Mai, J.; Alloosh, M.; Sturek, M.; Cheng, J.-X. Fast assessment of lipid content in arteries in vivo by intravascular photoacoustic tomography. Sci. Rep. 2018, 8, 2400. [CrossRef] [PubMed]

90. Yaseen, M.A.; Ermilov, S.A.; Brecht, H.-P.F.; Su, R.; Conjusteau, A.; Fronheiser, M.P.; Bell, B.A.; Motamedi, M.; Oraevsky, A.A. Optoacoustic imaging of the prostate: Development toward image-guided biopsy. J. Biomed. Opt. 2010, 15, 021310. [CrossRef] [PubMed]

91. Wang, B.; Karpiouk, A.; Yeager, D.; Amirian, J.; Litovsky, S.; Smalling, R.; Emelianov, S. Intravascular photoacoustic imaging of lipid in atherosclerotic plaques in the presence of luminal blood. Opt. Lett. 2012, 37, 1244-1246. [CrossRef] [PubMed]

92. Winawer, S.J.; Leinder, S.D.; Hajdu, S.I.; Sherlock, P. Colonoscopic biopsy and cytology in the diagnosis of colon cancer. Cancer 1978, 42, 2849-2853. [CrossRef]

93. Gado, A.; Ebeid, B.; Abdelmohsen, A.; Axon, A. Improving the Yield of Histological Sampling in Patients with Suspected Colorectal Cancer during Colonoscopy by Introducing a Colonoscopy Quality Assurance Program. Gastroenterol. Res. 2011, 4, 157-161. [CrossRef] [PubMed]

94. Van Rijn, J.C.; Reitsma, J.B.; Stoker, J.; Bossuyt, P.M.; van Deventer, S.J.; Dekker, E. Polyp miss rate determined by tandem colonoscopy: A systematic review. Am. J. Gastroenterol. 2006, 101, 343-350. [CrossRef]

95. Tsai, T.-H.; Ahsen, O.O.; Lee, H.-C.; Liang, K.; Figueiredo, M.; Tao, Y.K.; Giacomelli, M.G.; Potsaid, B.M.; Jayaraman, V.; Huang, Q.; et al. Endoscopic Optical Coherence Angiography Enables 3-Dimensional Visualization of Subsurface Microvasculature. Gastroenterology 2014, 147, 1219-1221. [CrossRef]

96. Harewood, G.C. Assessment of Clinical Impact of Endoscopic Ultrasound on Rectal Cancer. Am. J. Gastroenterol. 2004, 99, 623-627. [CrossRef]

97. Iseki, K.; Tatsuta, M.; Iishi, H.; Sakai, N.; Yano, H.; Ishiguro, S. Effectiveness of the near-infrared electronic endoscope for diagnosis of the depth of involvement of gastric cancers. Gastrointest. Endosc. 2000, 52, 755-762. [CrossRef]

98. Yuan, S.; Roney, C.A.; Wierwille, J.; Chen, C.-W.; Xu, B.; Griffiths, G.; Jiang, J.; Ma, H.; Cable, A.; Summers, R.M.; et al. Coregistered optical coherence tomography and fluorescence molecular imaging for simultaneous morphological and molecular imaging. Phys. Med. Biol. 2009, 55, 191-206. [CrossRef]

99. Mascagni, D.; Corbellini, L.; Urciuoli, P.; Di Matteo, G. Endoluminal ultrasound for early detection of local recurrence of rectal cancer. J. Br. Surg. 2005, 76, 1176-1180. [CrossRef]

100. Kirtane, T.S.; Wagh, M.S. Endoscopic Optical Coherence Tomography (OCT): Advances in Gastrointestinal Imaging. Gastroenterol. Res. Pract. 2014, 2014, 376367. [CrossRef] [PubMed] 
101. Kubo, T.; Akasaka, T. Optical coherence tomography imaging: Current status and future perspectives: Current and future developments in OCT. Cardiovasc. Interv. Ther. 2010, 25, 2-10. [CrossRef] [PubMed]

102. Yang, V.; Tang, S.-J.; Gordon, M.L.; Qi, B.; Gardiner, G.; Cirocco, M.; Kortan, P.; Haber, G.B.; Kandel, G.; Vitkin, I.A.; et al. Endoscopic Doppler optical coherence tomography in the human GI tract: Initial experience. Gastrointest. Endosc. 2005, 61, 879-890. [CrossRef]

103. Iftimia, N.; Iyer, A.K.; Hammer, D.X.; Lue, N.; Mujat, M.; Pitman, M.; Ferguson, R.D.; Amiji, M. Fluorescence-guided optical coherence tomography imaging for colon cancer screening: A preliminary mouse study. Biomed. Opt. Express 2011, 3, 178-191. [CrossRef] [PubMed]

104. Li, Y.; Jing, J.; Heidari, E.; Zhu, J.; Qu, Y.; Chen, Z. Intravascular Optical Coherence Tomography for Characterization of Atherosclerosis with a 1.7 Micron Swept-Source Laser. Sci. Rep. 2017, 7, 14525. [CrossRef]

105. Ughi, G.J.; Wang, H.; Gerbaud, E.; Gardecki, J.A.; Fard, A.M.; Hamidi, E.; Vacas-Jacques, P.; Rosenberg, M.; Jaffer, F.A.; Tearney, G.J. Clinical Characterization of Coronary Atherosclerosis With Dual-Modality OCT and Near-Infrared Autofluorescence Imaging. JACC Cardiovasc. Imaging 2016, 9, 1304-1314. [CrossRef]

106. Mavadia, J.; Xi, J.; Chen, Y.; Li, X. An all-fiber-optic endoscopy platform for simultaneous OCT and fluorescence imaging. Biomed. Opt. Express 2012, 3, 2851-2859. [CrossRef]

107. Li, Y.; Jing, J.; Yu, J.; Zhang, B.; Huo, T.; Yang, Q.; Chen, Z. Multimodality endoscopic optical coherence tomography and fluorescence imaging technology for visualization of layered architecture and subsurface microvasculature. Opt. Lett. 2018, 43, 2074-2077. [CrossRef]

108. Li, Y.; Zhu, Z.; Chen, J.; Jing, J.C.; Sun, C.-H.; Kim, S.; Chung, P.-S.; Chen, Z. Multimodal endoscopy for colorectal cancer detection by optical coherence tomography and near-infrared fluorescence imaging. Biomed. Opt. Express 2019, 10, 2419-2429. [CrossRef]

109. Li, Y.; Chen, J.; Chen, Z. Advances in Doppler optical coherence tomography and angiography. Transl. Biophotonics 2019, 1, e201900005. [CrossRef]

110. Li, Y.; Sudol, N.T.; Miao, Y.; Jing, J.C.; Zhu, J.; Lane, F.; Chen, Z. 1.7 micron optical coherence tomography for vaginal tissue characterization in vivo. Lasers Surg. Med. 2019, 51, 120-126. [CrossRef]

111. Li, Y.; Murthy, R.S.; Zhu, Y.; Zhang, F.; Tang, J.; Mehrabi, J.N.; Kelly, K.M.; Chen, Z. 1.7-micron Optical Coherence Tomography Angiography for Characterization of Skin Lesions-A Feasibility Study. IEEE Trans. Med. Imaging 2021. [CrossRef]

112. Swallow, R.; Court, I.; Calver, A.; Curzen, N. The limitations of coronary angiography: Identification of a critical coronary stenosis using intravascular ultrasound. Int. J. Cardiol. 2006, 106, 123-125. [CrossRef]

113. Nissen, S.E. Limitations of Computed Tomography Coronary Angiography. J. Am. Coll. Cardiol. 2008, 52, 2145-2147. [CrossRef] [PubMed]

114. Prati, F. Coronary computed tomography angiography in coronary heart disease: Clinical applications and limitations. G. Ital. Cardiol. 2019, 20, 409-416.

115. Nissen, S.E.; Yock, P. Intravascular ultrasound: Novel pathophysiological insights and current clinical applications. Circulation 2001, 103, 604-616. [CrossRef]

116. Mintz, G.S.; Weissman, N.J. Intravascular Ultrasound in the Drug-Eluting Stent Era. J. Am. Coll. Cardiol. 2006, 48, 421-429. [CrossRef] [PubMed]

117. Bermejo, J.; Botas, J.; Garcia, E.; Elizaga, J.; Osende, J.; Soriano, J.; Abeytua, M.; Delcan, J.L. Mechanisms of residual lumen stenosis after high-pressure stent implantation: A quantitative coronary angiography and intravascular ultrasound study. Circulation 1998, 98, 112-118. [CrossRef]

118. Hanekamp, C.E.E.; Koolen, J.J.; Pijls, N.H.J.; Michels, H.R.; Bonnier, H.J.R.M. Comparison of quantitative coronary angiography, intravascular ultrasound, and coronary pressure measurement to assess optimum stent deployment. Circulation 1999, 99, 1015-1021. [CrossRef] [PubMed]

119. Cilingiroglu, M.; Oh, J.H.; Sugunan, B.; Kemp, N.J.; Kim, J.; Lee, S.; Zaatari, H.N.; Escobedo, D.; Thompson, S.; Milner, T.E.; et al. Detection of vulnerable plaque in a murine model of athereosclerosis with optical coherence tomography. Catheter. Cardiovasc. Interv. 2006, 67, 915-923. [CrossRef]

120. Tearney, G.J.; Jang, I.-K.; Bouma, B.E. Optical coherence tomography for imaging the vulnerable plaque. J. Biomed. Opt. 2006, 11, 021002. [CrossRef]

121. Qu, Y.; Ma, T.; He, Y.; Yu, M.; Zhu, J.; Miao, Y.; Dai, C.; Patel, P.; Shung, K.K.; Zhou, Q.; et al. Miniature probe for mapping mechanical properties of vascular lesions using acoustic radiation force optical coherence elastography. Sci. Rep. 2017, 7, 4731. [CrossRef]

122. Villiger, M.; Karanasos, A.; Ren, J.; Lippok, N.; Shishkov, M.; Van Soest, G.; Nadkarni, S.; Regar, E.; Bouma, B.E. Intravascular polarization sensitive optical coherence tomography in human patients. In Proceedings of the CLEO: Applications and Technology, San Jose, CA, USA, 5-10 June 2016.

123. Sawada, T.; Shite, J.; Garcia-Garcia, H.M.; Shinke, T.; Watanabe, S.; Otake, H.; Matsumoto, D.; Tanino, Y.; Ogasawara, D.; Kawamori, H.; et al. Feasibility of combined use of intravascular ultrasound radiofrequency data analysis and optical coherence tomography for detecting thin-cap fibroatheroma. Eur. Heart J. 2008, 29, 1136-1146. [CrossRef] [PubMed]

124. Puri, R.; Worthley, M.I.; Nicholls, S.J. Intravascular imaging of vulnerable coronary plaque: Current and future concepts. Nat. Rev. Cardiol. 2011, 8, 131-139. [CrossRef] [PubMed] 
125. Karlsson, S.; Anesäter, E.; Fransson, K.; Andell, P.; Persson, J.; Erlinge, D. Intracoronary near-infrared spectroscopy and the risk of future cardiovascular events. Open Heart 2019, 6, e000917. [CrossRef]

126. Madder, R.D.; Van Oosterhout, S.; Klungle, D.; Mulder, A.; Elmore, M.; Decker, J.M.; Langholz, D.; Boyden, T.F.; Parker, J.; Muller, J.E. Multimodality Intracoronary Imaging with Near-Infrared Spectroscopy and Intravascular Ultrasound in Asymptomatic Individuals with High Calcium Scores. Circ. Cardiovasc. Imaging 2017, 10, e006282. [CrossRef] [PubMed]

127. Hoang, V.; Grounds, J.; Pham, D.; Virani, S.; Hamzeh, I.; Qureshi, A.M.; Lakkis, N.; Alam, M. The Role of Intracoronary Plaque Imaging with Intravascular Ultrasound, Optical Coherence Tomography, and Near-Infrared Spectroscopy in Patients with Coronary Artery Disease. Curr. Atheroscler. Rep. 2016, 18, 57. [CrossRef]

128. Calfon, M.A.; Rosenthal, A.; Mallas, G.; Mauskapf, A.; Nudelman, R.N.; Ntziachristos, V.; Jaffer, F.A. In vivo Near Infrared Fluorescence (NIRF) Intravascular Molecular Imaging of Inflammatory Plaque, a Multimodal Approach to Imaging of Atherosclerosis. J. Vis. Exp. 2011, 54, e2257. [CrossRef]

129. Hara, T.; Jaffer, F.A. Intravascular NIRF Molecular Imaging Approaches in Coronary Artery Disease. Curr. Cardiovasc. Imaging Rep. 2016, 9, 13. [CrossRef]

130. Li, Y.; Chen, Z. Multimodal intravascular photoacoustic and ultrasound imaging. Biomed. Eng. Lett. 2018, 8, 193-201. [CrossRef]

131. Li, Y.; Chen, J.; Chen, Z. Multimodal intravascular imaging technology for characterization of atherosclerosis. J. Innov. Opt. Health Sci. 2019, 13, 20300013. [CrossRef]

132. Wang, B.; Emelianov, S. Thermal intravascular photoacoustic imaging. Biomed. Opt. Express 2011, 2, 3072-3078. [CrossRef]

133. Yeager, D.; Karpiouk, A.; Wang, B.; Amirian, J.; Sokolov, K.; Smalling, R.; Emelianov, S. Intravascular photoacoustic imaging of exogenously labeled atherosclerotic plaque through luminal blood. J. Biomed. Opt. 2012, 17, 106016. [CrossRef]

134. Brodie, G.W.; Qiu, Y.; Cochran, S.; Spalding, G.; MacDonald, M. Letters: Optically transparent piezoelectric transducer for ultrasonic particle manipulation. IEEE Trans. Ultrason. Ferroelectr. Freq. Control 2014, 61, 389-391. [CrossRef]

135. Chen, H.; Agrawal, S.; Dangi, A.; Wible, C.; Osman, M.; Abune, L.; Jia, H.; Rossi, R.; Wang, Y.; Kothapalli, S.-R. Optical-Resolution Photoacoustic Microscopy Using Transparent Ultrasound Transducer. Sensors 2019, 19, 5470. [CrossRef] [PubMed]

136. Dangi, A.; Agrawal, S.; Kothapalli, S.-R. Lithium niobate-based transparent ultrasound transducers for photoacoustic imaging. Opt. Lett. 2019, 44, 5326-5329. [CrossRef] [PubMed]

137. Qiu, C.; Wang, B.; Zhang, N.; Zhang, S.; Liu, J.; Walker, D.; Wang, Y.; Tian, H.; Shrout, T.R.; Xu, Z.; et al. Transparent ferroelectric crystals with ultrahigh piezoelectricity. Nature 2020, 577, 350-354. [CrossRef] [PubMed]

138. Chen, H.; Osman, M.; Mirg, S.; Agrawal, S.; Cai, J.; Dangi, A.; Kothapalli, S.-R. Transparent ultrasound transducers for multiscale photoacoustic imaging. In Proceedings of the Photons Plus Ultrasound: Imaging and Sensing 2021, Online, 5 March 2021.

139. Sheinfeld, A.; Gilead, S.; Eyal, A. Photoacoustic Doppler measurement of flow using tone burst excitation. Opt. Express 2010, 18, 4212-4221. [CrossRef] [PubMed]

140. Sheinfeld, A.; Gilead, S.; Eyal, A. Simultaneous spatial and spectral mapping of flow using photoacoustic Doppler measurement. J. Biomed. Opt. 2010, 15, 066010. [CrossRef] [PubMed]

141. Esenaliev, R.O.; Oraevsky, A.; Larin, K.V.; Larina, I.V.; Motamedi, M. Real-time optoacoustic monitoring of temperature in tissues. Laser-Tissue Interact. X Photochem. Photothermal. Photomech. 1999, 3601, 268-276. [CrossRef]

142. Schüle, G.; Hüttmann, G.; Framme, C.; Roider, J.; Brinkmann, R. Noninvasive optoacoustic temperature determination at the fundus of the eye during laser irradiation. J. Biomed. Opt. 2004, 9, 173-179. [CrossRef] [PubMed]

143. Pramanik, M.; Wang, L. Thermoacoustic and photoacoustic sensing of temperature. J. Biomed. Opt. 2009, 14, 054024. [CrossRef] [PubMed]

144. Dai, X.; Yang, H.; Shan, T.; Xie, H.; Berceli, S.A.; Jiang, H. Miniature Endoscope for Multimodal Imaging. ACS Photonics 2016, 4, 174-180. [CrossRef]

145. Leng, J.; Zhang, J.; Li, C.; Shu, C.; Wang, B.; Lin, R.; Liang, Y.; Wang, K.; Shen, L.; Lam, K.-H.; et al. Multi-spectral intravascular photoacoustic/ultrasound/optical coherence tomography tri-modality system with a fully-integrated 09-mm full field-of-view catheter for plaque vulnerability imaging. Biomed. Opt. Express 2021, 12, 1934-1946. [CrossRef]

146. Zhan, K.; Wang, L.; Chen, Z.; Xing, D. Intravascular Photoacoustic and Autofluorescence Imaging for Detecting Intraplaque Hemorrhage: A Feasibility Study. IEEE J. Sel. Top. Quantum Electron. 2021, 27, 7100105. [CrossRef]

147. Li, Y.; Moon, S.; Chen, J.J.; Zhu, Z.; Chen, Z. Ultrahigh-sensitive optical coherence elastography. Light. Sci. Appl. 2020, 9, 58. [CrossRef]

148. Li, Y.; Zhu, J.; Chen, J.; Yu, J.; Jin, Z.; Miao, Y.; Browne, A.W.; Zhou, Q.; Chen, Z. Simultaneously imaging and quantifying in vivo mechanical properties of crystalline lens and cornea using optical coherence elastography with acoustic radiation force excitation. APL Photonics 2019, 4, 106104. [CrossRef] 